NBER WORKING PAPER SERIES

\title{
LIQUIDITY TRANSFORMATION IN ASSET MANAGEMENT: EVIDENCE FROM THE CASH HOLDINGS OF MUTUAL FUNDS
}

\author{
Sergey Chernenko \\ Adi Sunderam \\ Working Paper 22391 \\ http://www.nber.org/papers/w22391 \\ NATIONAL BUREAU OF ECONOMIC RESEARCH \\ 1050 Massachusetts Avenue \\ Cambridge, MA 02138 \\ July 2016
}

We thank Jules van Binsbergen, Jaewon Choi, Lauren Cohen, Robin Greenwood, Johan Hombert, Marcin Kacperczyk, Xuewen Liu, Alexi Savov, Jeremy Stein, René Stulz, Robert Turley, Jeff Wang, Zhi Wang, Michael Weisbach, Yao Zeng, and seminar participants at the 3rd Annual Conference on Financial Market Regulation, Adam Smith Conference, Duke/UNC Asset Pricing Conference, Federal Reserve Bank of New York, NBER New Developments in Long-Term Asset Management Conference, Ohio State University, Risk Management Conference Mont Tremblant, Texas A\&M, University of Illinois Urbana-Champaign, and University of Massachusetts at Amherst for helpful comments and suggestions. Yuan He and Mike Dong provided excellent research assistance. The views expressed herein are those of the authors and do not necessarily reflect the views of the National Bureau of Economic Research.

NBER working papers are circulated for discussion and comment purposes. They have not been peer-reviewed or been subject to the review by the NBER Board of Directors that accompanies official NBER publications.

(C) 2016 by Sergey Chernenko and Adi Sunderam. All rights reserved. Short sections of text, not to exceed two paragraphs, may be quoted without explicit permission provided that full credit, including $(\odot)$ notice, is given to the source. 
Liquidity Transformation in Asset Management: Evidence from the Cash Holdings of Mutual Funds

Sergey Chernenko and Adi Sunderam

NBER Working Paper No. 22391

July 2016

JEL No. G20,G23

\begin{abstract}
We study liquidity transformation in mutual funds using a novel data set on their cash holdings. To provide investors with claims that are more liquid than the underlying assets, funds engage in substantial liquidity management. Specifically, they hold substantial amounts of cash, which they use to accommodate inflows and outflows rather than transacting in the underlying portfolio assets. This is particularly true for funds with illiquid assets and at times of low market liquidity. We provide evidence suggesting that mutual funds' cash holdings are not large enough to fully mitigate price impact externalities created by the liquidity transformation they engage in.
\end{abstract}

\author{
Sergey Chernenko \\ The Ohio State University \\ 2100 Neil Avenue \\ 818 Fisher Hall \\ Columbus, $\mathrm{OH} 43210$ \\ sergey.chernenko@fisher.osu.edu \\ Adi Sunderam \\ Harvard Business School \\ Baker Library 359 \\ Soldiers Field \\ Boston, MA 02163 \\ and NBER \\ asunderam@hbs.edu
}




\section{Introduction}

Liquidity transformation - the creation of liquid claims that are backed by illiquid assets - is a key function of many financial intermediaries. A long literature, starting with Diamond and Dybvig (1983) and Gorton and Pennacchi (1990), argues, for example, that the purpose of banks is to provide investors with highly liquid demand deposits while financing illiquid, information intensive loans. Liquidity transformation is also an important function of the system of marketbased intermediaries known as the shadow banking system, as argued by Gorton and Metrick (2010), Kacperczyk and Schnabl (2010), Krishnamurthy and Vissing-Jorgenson (2015), Moreira and Savov (2016), and Nagel (2016).

Through open-ending - allowing investors to withdraw capital at short notice traditional asset managers provide liquidity services that are similar to banks and shadow banks. For example, though they may invest in illiquid assets such as corporate bonds, bank loans, and emerging market stocks, open-end mutual funds have liquid liabilities. Specifically, mutual funds allow investors to redeem any number of shares at the fund's end-of-day net asset value (NAV), effectively pooling liquidation costs across investors. In contrast, investors who directly hold the underlying investments bear their own liquidation costs when selling those assets.

Can liquidity transformation by asset managers cause financial stability problems? This question has been the subject of a vigorous debate among academics, practitioners, and regulators (e.g., Goldstein et al, 2015; International Monetary Fund, 2015; Financial Stability Oversight Council, 2014; Feroli et al, 2014; Chen, Goldstein, and Jiang, 2010). A key concern on one side of the debate is that liquidity transformation increases the scope for fire sales. Redemptions from an open-ended fund can force sales of illiquid assets, depressing asset prices and thereby stimulating further redemptions and fire sales. Motivated by such concerns, the Securities and Exchange Commission (SEC) has recently proposed new rules to promote more effective liquidity risk management by mutual funds (SEC, 2015).

On the opposite side of the debate are two main arguments. First, many contend that asset managers are essentially a veil, simply transacting in the underlying equities and bonds on behalf of investors without performing much liquidity transformation (Investment Company Institute, 2015). Second, others argue that asset managers are well aware of the risks of fire sales and take 
steps to manage their liquidity needs (Independent Directors Council, 2016; Investment Company Institute, 2016).

A key empirical challenge in this debate is that it is difficult to measure liquidity transformation for asset managers. For banks and shadow banks, maturity mismatch - the difference in maturity between assets and liabilities - provides a reasonable measure of liquidity transformation. While investors can withdraw unlimited quantities of deposits without any price impact, bank loans cannot be traded before maturity without creating substantial price impact. For asset managers, however, there is no comparable measure. Their assets are typically tradeable securities, though with varying levels of liquidity. Furthermore, some price impact can be passed on to investors because they own claims whose value is not fixed. Nevertheless, asset managers perform some amount of liquidity transformation because their ability to pool trades and space transactions over time flattens the price-quantity schedule faced by their investors.

In this paper, we use the cash holdings of mutual funds that invest in equities and longterm corporate bonds as a window into the liquidity transformation activities of asset managers. ${ }^{1}$ Our key insight is that the way mutual funds manage their own liquidity to provide the benefits of open-ending to investors is a measure of how much liquidity transformation funds are performing. A fund acting as a pure pass-through, simply buying and selling the underlying assets on behalf of its investors, has little need for cash holdings to manage its liquidity. In contrast, a fund performing substantial liquidity transformation will seek to use cash holdings to mitigate the costs associated with providing investors with claims that are more liquid than the underlying assets. This revealed preference argument thus suggests that funds' cash management practices can be used to measure their liquidity transformation.

Two features of the mutual fund industry make it a good laboratory for studying liquidity transformation by asset managers. First, mutual funds account for a large fraction of the overall asset management industry. As of 2015Q1, mutual funds had aggregate assets of \$12.9 trillion and held $20.5 \%$ of corporate equities and $20.6 \%$ of corporate and foreign bonds. ${ }^{2}$ Second, while

\footnotetext{
${ }^{1}$ Because we focus on the mismatch in liquidity between fund assets and liabilities, we exclude money market mutual funds, closed end funds, index funds, ETFs, and short-term bond mutual funds from our analysis.

${ }^{2}$ Federal Reserve Flow of Funds. These numbers do not include the assets of money market mutual funds.
} 
other asset managers have some ability to restrict investor redemptions, most mutual funds are completely open-ended, creating significant scope for liquidity transformation.

We study mutual fund liquidity management using a novel data set on the cash holdings of equity and long-term corporate bond funds collected from SEC form N-SAR filings. Importantly, our data set covers holdings of both cash and cash substitutes such as money market mutual fund shares. Cash substitutes have become an increasingly important source of liquidity for asset managers in recent years. The IMF estimates that asset managers as a whole held about $\$ 2$ trillion of cash and cash substitutes in 2013 (Pozsar, 2013). This is approximately the same amount as US corporations (Bates et al., 2009). Approximately 37\% of asset manager holdings is in the form of cash substitutes (Pozsar, 2013). Fig. 1 shows that a similar pattern holds for the equity and long-term bond mutual funds in our data set. By 2014, they held $\$ 600$ billion of cash and cash substitutes, with nearly $50 \%$ taking the form of cash substitutes.

We present four main results on mutual fund liquidity management, all showing that mutual funds do not simply act as pass-throughs. Instead, consistent with the idea that mutual funds perform a significant amount of liquidity transformation, funds use holdings of cash to actively manage their liquidity provision and to reduce their impact on the prices of the underlying assets. Our first main result is that, rather than transacting in equities and bonds, mutual funds use cash to accommodate inflows and outflows. Funds build up cash positions when they receive inflows and draw down cash when they suffer outflows. The magnitudes are economically significant. For each dollar of inflows or outflows in a given month, 23 to 33 cents of that flow is accommodated through changes in cash rather than through trading in the fund's portfolio securities. This impact of flows on cash balances lasts for multiple months.

Second, asset liquidity affects the propensity of funds to use cash holdings to manage fund flows. In the cross section, funds with illiquid assets are more aggressive in using cash to meet inflows and outflows. A one-standard deviation increase in asset illiquidity is associated with a $20-30 \%$ increase in the fraction of fund flows accommodated through changes in cash. We find similar evidence in the time series: during periods of low aggregate market liquidity, funds accommodate a larger fraction of fund flows with cash. These results would not obtain if funds were simply a veil, trading on behalf of their investors. Instead, our results are consistent with 
the idea that mutual funds perform a significant amount of liquidity transformation, with their cash holdings playing a critical role.

Third, we show that funds that perform more liquidity transformation hold significantly more cash. Asset illiquidity, the volatility of fund flows, and their interaction are the key determinants of how much liquidity transformation a given fund engages in, and we find that all three variables are strongly related to cash holdings. For equity funds, for example, a onestandard deviation increase in asset illiquidity (flow volatility) is associated with a 1.0 (0.4) percentage points higher cash-to-assets ratio. Furthermore, the interaction of asset illiquidity and flow volatility is positive and statistically significant, indicating that funds that invest in illiquid assets and provide investors with ample liquidity have particularly high cash-to-assets ratios. The magnitude of these effects is large. For funds with the most liquid assets in our sample, cash holdings do not vary with flow volatility, indicating that these funds are close to the frictionless null. However, the average fund is quite far from this frictionless benchmark. Overall, because they use cash to manage liquidity, mutual funds hold large aggregate amounts of cash.

Are these cash holdings large enough to fully mitigate any price impact externalities that funds may exert on other market participants? We provide two pieces of suggestive evidence that they are not. The first piece of evidence arises from the intuition that a monopolist internalizes its price impact. We show that funds that hold a larger fraction of the outstanding amount of the assets they invest in tend to hold more cash. This finding is consistent with such funds more fully internalizing the price impact of their trading in the securities they hold. Our second piece of evidence is at the fund family level. We show that funds that have significant holdings overlap with other funds in the same family hold more cash. This finding is consistent with the idea that these funds are more cautious about exerting price impact when it may adversely affect other funds in the family.

We also explore the extent to which funds use alternative liquidity management tools, including redemption restrictions, credit lines, and interfund lending programs in lieu of cash. Our evidence indicates that these alternative tools are imperfect substitutes for cash and that cash is the key tool funds use for liquidity management. These results validate our insight that cash holdings are a good measure of a fund's liquidity transformation activities. 
In summary, our analysis highlights three key properties of liquidity transformation in asset management. First, it is economically significant. Mutual funds are not a veil, simply transacting in bonds and equities on behalf of their investors. Instead, funds have substantial cash holdings and use them to accommodate inflows and outflows, even at horizons of a few months.

Second, liquidity transformation in asset management is highly dependent on liquidity provision by the traditional and shadow banking sectors. In order to provide liquidity to their investors, mutual funds must hold substantial amounts of cash, bank deposits, and money market mutual fund shares. These holdings do not decrease much with fund size, suggesting that economies of scale in liquidity provision are weak.

Third, despite their size, the cash holdings of mutual funds are not sufficiently large to completely mitigate the price impact externalities created by funds' liquidity transformation activities. Our evidence suggests that funds do not fully internalize the effect that providing investors with daily liquidity has on the prices of the underlying securities.

Our paper is related to several strands of the literature. First, there is a small but growing literature studying the potential for liquidity transformation among mutual funds to generate runlike dynamics, including Chen, Goldstein, and Jiang (2010), Feroli et al (2014), Goldstein, Jiang, and Ng (2015), Wang (2015), and Zeng (2015). Second, there is a large theoretical and empirical literature studying fire sales in debt and equity markets, including Shleifer and Vishny (1992), Shleifer and Vishny (1997), Coval and Stafford (2007), Ellul, Jotikasthira and Lundblad (2011), Greenwood and Thesmar (2011), and Merrill et al (2012). ${ }^{3}$ Our results show how mutual funds use cash holdings to manage the risk of fire sales created by their liquidity transformation activities and suggest that they may not hold enough cash to fully mitigate fire sale externalities.

Our paper is also related to the large literature on liquidity transformation in banks, including recent empirical work measuring liquidity creation in banks such as Berger and Bouwman (2009) and Cornett et al (2011). It is also related to the literature on instabilities in

\footnotetext{
${ }^{3}$ In addition, there is a broader literature on debt and equity market liquidity, including Roll (1984), Amihud and Mendelsohn (1986), Chordia, Roll, and Subrahmanyam (2001), Amihud (2002), Longstaff (2004), Acharya and Pedersen (2005), Bao, Pan, and Wang (2011), Dick-Nielsen, Feldhütter, and Lando (2012), Feldhütter (2012), and many others. Our results demonstrate that asset managers perform liquidity transformation in a manner similar to banks, providing investors with liquid claims while holding less liquid securities, which they must ultimately trade in the debt and equity markets.
} 
shadow banking, including Gorton and Metrick (2012), Stein (2012), Kacperczyk and Schnabl (2013), Krishnamurthy, Nagel, and Orlov (2014), Chernenko and Sunderam (2014), and Schmidt, Timmerman, and Wermers (2016).

Finally, we contribute to a small but growing literature on the determinants and effects of mutual fund cash holdings, including Yan (2006), Simutin (2014), and Hanouna, Novak, Riley, and Stahel (2015). While this literature focuses primarily on funds' market timing ability and the impact cash holdings have on returns, we use cash holdings as a measure of liquidity transformation. We empirically validate this measure and use it to argue that mutual funds perform a substantial amount of liquidity transformation. In addition, we use the measure to examine the extent to which funds internalize the price impact they exert on security prices.

The remainder of the paper is organized as follows. Section II presents a simple framework that demonstrates the link between liquidity transformation and optimal cash holdings. Section III describes the data. Section IV presents our main results on cash management by mutual funds. Section V provides evidence on how much of their price impact individual mutual funds internalize. Section VI discusses alternative liquidity management tools and argues that they play a secondary role relative to cash holdings, and Section VII concludes.

\section{Framework}

Throughout the paper, we use liquidity transformation to mean that the price-quantity schedule faced by a fund investor in buying or selling fund shares is different from what it would be if the investor directly traded in the underlying assets.

There are three main ways mutual funds can perform liquidity transformation. First, funds allow investors to buy and sell unlimited quantities at the end-of-day NAV. In contrast, individual investors trading by themselves would create more price impact if they traded larger quantities. Second, funds can use cash buffers to pool investor buy and sell orders that may be asynchronous. Essentially, if some fraction of fund flows are temporary and will be offset in the near future, the fund can use cash buffers to net these flows. This is analogous to the way diversification across depositors allows banks to hold illiquid assets, as in Diamond and Dybvig (1983). Individual investors trading for themselves in a market would achieve this only if they traded simultaneously. Third, funds can use cash buffers to mitigate price impact when trading in the underlying assets. If price impact is increasing in the quantity traded but temporary, then 
funds can use cash buffers to spread out their trades across time in order to reduce their price impact. Similarly, if market liquidity varies over time, funds can use cash buffers to allocate their trades to periods with low price impact.

\section{A. Cash management}

To help fix ideas, we begin by outlining the logic of our empirical tests. In the Appendix, we present a simple static model that formally derives many of these predictions. We consider a fund charged with managing a pool of risky, illiquid assets to outperform a benchmark while providing regular liquidity to its investors. Our predictions are based on the idea that an optimizing fund will use cash buffers to help meet this mandate. The key tradeoff the fund faces is that cash buffers help reduce price impact when trading the illiquid assets, but they have a carrying cost because they increase tracking error relative to the benchmark.

We conduct three sets of empirical tests. The first one involves fund cash management practices.

Prediction 1. A fund's propensity to use cash to accommodate flows is a measure of its liquidity transformation.

The logic here is that if fund assets were perfectly liquid, the fund would have no need to use cash. It could always trade in the underlying assets immediately and frictionlessly, so holding cash buffers would only increase the fund's tracking error. On the other hand, if the fund is performing liquidity transformation, it can use its cash buffers to mitigate the price impact associated with trading in the underlying. The same logic suggests that the strength of this cash management motive varies with the illiquidity of the underlying assets.

Prediction 2. In both the cross section and the time series, funds performing more liquidity transformation should more aggressively use cash to accommodate flows.

The more illiquid fund assets are, the longer the fund will take to accommodate flows. The reason is that when assets are more illiquid, costs of delay become smaller relative to the price impact of trading. Similarly, when assets are more illiquid, the value of waiting for offsetting flows increases. Assets can be more illiquid either because of the fund's choice of assets (e.g., small cap versus large cap stocks) or because of aggregate variation in market liquidity. 


\section{B. Cash holdings for a single fund}

Our next set of empirical tests involves the level of cash holdings.

\section{Prediction 3. The level of cash holdings is a measure of equilibrium liquidity transformation.}

This may seem somewhat counterintuitive, as all else equal, more cash reduces the amount of liquidity transformation the fund is doing. In the limit, a fund holding only cash does not perform any liquidity transformation. However, the prediction is about funds' optimal equilibrium behavior. The logic is that funds trade off the incremental carrying costs of having more cash against the expected incremental trading costs associated with having less cash.

It follows from the fund's trade off that optimal cash reserves are increasing in the fund's expected trading costs. Intuitively, if the fund chooses to hold more cash, it is choosing to pay higher carrying costs. This is optimal only if the fund faces higher expected trading costs. Furthermore, a fund with higher expected trading costs will not hold enough cash to fully offset those costs. The fund always bears the incremental carrying costs but enjoys reduced trading costs only when there are large outflows. Thus, a fund's optimal cash holdings are increasing in the amount of liquidity transformation it performs.

Prediction 4. If cash holdings are driven by liquidity transformation, they should increase with asset illiquidity, the volatility of fund flows, and the interaction of the two.

Liquidity transformation is driven by the intersection of investor behavior and asset illiquidity. Funds with more volatile flows are effectively providing greater liquidity services to their investors. Similarly, if the fund's assets are more illiquid, it is providing greater liquidity services to its investors. These two effects interact: the more illiquid the assets, the stronger the relationship between cash-to-assets ratios and flow volatility.

\section{Internalizing price impact}

Our third set of predictions involves the extent to which fund cash holdings are high enough to prevent funds from exerting price impact externalities on one another. We consider the alternative, where the level of cash holdings is picked by a planner minimizing total costs (carrying costs of cash plus trading costs incurred by funds) borne by all funds.

Prediction 5. A planner coordinating the level of cash holdings among funds would choose a higher level than the level chosen in the private market equilibrium. 
This is the analog of a leverage or fire sale externality as in Shleifer and Vishny (1992) or Stein (2012). In the private market equilibrium, each individual fund treats other funds' reserve policies as fixed when choosing its own reserves. An individual fund does not internalize this positive effect its cash holdings have on trading costs faced by the other funds. Specifically, when an individual fund has more cash, it needs to trade less and thus creates less price impact. This benefits other funds that need to trade in the same direction as the individual fund. In contrast, the planner internalizes the fact that high reserves benefit all funds through lower liquidation costs.

Note that there is no welfare statement here. For there to be a social loss from low cash holdings in general equilibrium, the liquidation costs to the funds must not simply be a transfer to an outside liquidity provider. Our prediction is simply that coordination among funds would lead to higher cash holdings.

A corollary that follows from this logic is that a monopolist in a particular security internalizes its price impact, particularly if that security is illiquid. The externality that makes private market cash holdings lower than what a planner would choose arises because funds take into account how cash holdings mitigate their own price impact but not how that price impact affects other funds. Of course, if one fund owns the whole market, there is no externality. When a monopolist creates price impact through trading, it is the only fund that suffers because it is the only one that holds the security. Put differently, the monopolist and the planner solve the same problem: minimizing the sum of cash carrying costs and trading costs in the security. Generalizing this intuition, the higher is the fraction of the underlying assets owned by a given fund, the more will the fund internalize its price impact.

Corollary: Funds that own a larger fraction of their portfolio assets more fully internalize their price impact and therefore hold more cash reserves.

\section{III.Data}

\section{A. Cash holdings}

We combine novel data on the cash holdings of mutual funds with several other data sets. Our primary data comes from SEC form N-SAR filings. These forms are filed semi-annually by all mutual funds and provide data on asset composition, including holdings of cash and cash

substitutes. Specifically, we measure holdings of cash and cash substitutes as the sum of cash 
(item 74A), repurchase agreements (74B), short-term debt securities other than repurchase agreements (74C), and other investments (74I). Short-term debt securities have remaining maturities of less than a year and consist mostly of US Treasury Bills and commercial paper. The demarcation between cash and other assets is less clear for bond funds than for equity funds because bond funds may hold short-term debt for both liquidity management and pure investment reasons. We focus on long-term bond funds for this reason, but our measures of cash are still likely to be more noisy for bond funds than equity funds.

The other investments category (74I) consists mostly of investments in money market mutual funds (MMMFs), other mutual funds, loan participations, and physical commodities. Using hand-collected data, we have examined the composition of the other investments category for a random sample of 320 funds for which other investments accounted for at least $10 \%$ of total net assets. The mean and median fractions of MMMFs in other investments were $75 \%$ and $100 \%$. Holdings of other mutual funds accounted for most of the remaining value of other investments. We use our security-level holdings data, described below, to subtract holdings of long-term mutual funds from other investments. Otherwise, we treat the other investments category as consisting entirely of MMMFs. This should only introduce measurement error into our dependent variable and potentially inflate our standard errors. ${ }^{4}$

Our dependent variable is thus the sum of cash and cash equivalents scaled by TNA (item 74T). We winsorize this cash ratio at the $1^{\text {st }}$ and $99^{\text {th }}$ percentiles.

In addition to data on asset composition, form N-SAR contains data on fund flows and investment practices. Gross and net fund flows for each month since the last semi-annual filing are reported in item 28. Item 70 reports indicators for whether the fund uses various types of derivatives, borrows, lends out it securities, or engages in short sales. ${ }^{5}$

\footnotetext{
${ }^{4}$ The CRSP Mutual Fund Database includes a variable called per_cash that is supposed to report the fraction of the fund's portfolio invested in cash and equivalents. This variable appears to be a rather noisy proxy for the cash-toassets ratio. Aggregate cash holdings of all long-term mutual funds in CRSP track aggregate holdings of liquid assets of long-term mutual funds as reported by the Investment Company Institute (ICI) until 2007, but the relationship breaks down after that. By 2014, there is a gap of more than $\$ 400$ billion, or more than $50 \%$ of the aggregate cash holdings reported by ICI. At a more granular level, we calculated cash holdings form the bottom up using security-level data from the SEC form N-CSR for a random sample of 100 funds. The correlation between the true value of cash-to-assets ratio computed using N-CSR data and our N-SAR based proxy is 0.75 . The correlation between the true value and CRSP is only 0.40 .

5 Almazan et al (2004) also use form N-SAR's investment practices data.
} 


\section{B. Link to CRSP mutual fund database}

For additional fund characteristics such as investment objective, fraction of institutional share classes, and holdings liquidity, we link our N-SAR data to the CRSP Mutual Fund Database. Using a name-matching algorithm, we can match the majority of funds in N-SAR to CRSP. ${ }^{6}$ We match more than $70 \%$ of all fund-year observations in N-SAR to CRSP. In dollar terms, we match more than $80 \%$ of all assets.

After linking our data to CRSP, we apply the following screens to our sample of funds. We focus on open-end funds and exclude exchange-traded funds (ETFs), ${ }^{7}$ small business investment companies (SBIC), unit investment trusts (UIT), variable annuities, funds of funds, ${ }^{8}$ and money market mutual funds. In addition, we exclude observations with zero assets according to N-SAR and those for which the financial statements do not cover a regular 6- or 12-month reporting period. As we discuss below, we are able to measure asset liquidity for domestic equity funds, identified using CRSP objective codes starting with ED, and for long-term corporate bond funds. ${ }^{9}$ To further make sure that we can accurately measure fund flow volatility and asset liquidity, we focus on funds with at least $\$ 100$ million in assets. Finally, we exclude index funds for two reasons. First, index funds are likely to have higher carrying costs (i.e., costs of tracking error) than other funds. Thus, for index funds, cash holdings are likely to be lower and less sensitive to asset liquidity and fund flow volatility, and therefore a noisier measure of liquidity

\footnotetext{
${ }^{6}$ Our procedure takes advantage of the structure of fund names in CRSP. The full fund name in CRSP is generally of the form "trust name: fund name; share class." For example, "Vanguard Index Funds: Vanguard 500 Index Fund; Admiral Shares." The first piece, "Vanguard Index Funds," is the name of the legal trust that offers Vanguard 500 Index Fund as well as a number of other funds. Vanguard Index Funds is the legal entity that files on behalf of Vanguard 500 Index Fund with the SEC. The second piece, "Vanguard 500 Index Fund," is the name of the fund itself. The final piece, "Admiral Shares," indicates different share classes that are claims on the same portfolio but that offer different bundles of fees, minimum investment requirements, sales loads, and other restrictions.

${ }^{7}$ ETFs operate a very different model of liquidity transformation. They rely on investors to provide liquidity in the secondary market for the fund's share and on authorized participants (APs) to maintain parity between the market price of the fund's shares and their NAV. In untabulated results, we find that ETFs hold significantly less cash and that to the extent that they do hold more than a token amount of cash, it is almost entirely due to securities lending and derivatives trading.

${ }^{8}$ SBICs, UITs, and open-end funds are identified based on N-SAR items 5, 6, and 27. ETFs are identified based on the ETF dummy in CRSP or fund name including the words ETF, exchange-traded, iShares, or PowerShares. Variable annuities are identified based on N-SAR item 58. We use security-level data from CRSP and Morningstar to calculate the share of the portfolio invested in other mutual funds. Funds that, on average, invest more than $80 \%$ of their portfolio in other funds are considered to be funds of funds.

${ }^{9}$ Corporate bond funds are defined as funds that have Lipper objective codes A, BBB, HY, IID, MSI, and MSI and that invest more than $50 \%$ of their portfolio in intermediate and long-term corporate bonds (NSAR item 62P).
} 
transformation. Second, index funds largely track the most liquid securities, so there is little variation in asset liquidity for us to analyze among them.

\section{Asset liquidity}

We use holdings data from the CRSP Mutual Fund Database to measure the liquidity of equity mutual fund holdings. ${ }^{10}$ These data start in 2003. Following Chen, Goldstein, and Jiang (2010), we construct the square root version of the Amihud (2002) liquidity measure for each stock. We then aggregate up to the fund-quarter level, taking the value-weighted average of individual stock liquidity.

For bond funds, we use monthly holdings data from Morningstar, which covers the 2002Q2-2012Q2 period. Following Dick-Nielsen, Feldhütter, and Lando (2012) we measure liquidity of individual bonds as $\lambda$, the equal-weighted average of four other liquidity measures: Amihud, Imputed Roundtrip Cost (IRC) of Feldhutter (2012), Amihud risk, and IRC risk. ${ }^{11}$ The latter two are the standard deviations of the daily values of Amihud and IRC within a given quarter. Once we have the $\lambda$ measure for each bond, we aggregate up to the fund level, taking the value-weighted average of individual bond liquidity.

\section{Summary statistics}

Our final data set is a semi-annual fund-level panel that combines the N-SAR data with additional fund information from CRSP and data on asset liquidity from CRSP and Morningstar. Throughout the paper, we conduct our analysis at the fund-half year level.

The sample periods are determined by the availability of holdings data in CRSP and Morningstar and of bond transaction data in TRACE. For equity funds, the sample period is January 2003 - December 2014. For bond funds, it is September 2002 - June 2012.

Table 1 reports basic summary statistics for funds in our data, splitting them into equity versus bond funds. Our sample of equity funds consists of about 22,000 observations. Our sample of bond funds is much smaller, only about one eight the size of the equity fund sample. ${ }^{12}$

\footnotetext{
${ }^{10}$ In unreported analyses, we obtain very similar results when we use Thomson Reuters Mutual Funds Holdings data.

${ }^{11}$ We are grateful to Peter Feldhütter for sharing his code with us.

${ }^{12}$ The number of bond funds in our sample is significantly smaller than the number of equity funds because we focus on bond funds that invest at least $50 \%$ of their portfolio in corporate bonds.
} 
Equity and bond funds are broadly comparable in size with median TNA of $\$ 500-600$ million and mean TNA of $\$ 2.1-2.5$ billion.

Bond funds tend to hold more cash. The median bond fund has a cash-to-assets ratio of $5.3 \%$, while the median equity fund has a cash-to-assets ratio of $4.4 \%$. Bond funds have significantly higher turnover. ${ }^{13}$ The volatility of fund flows is comparable for bond and equity funds, averaging approximately $9-10 \%$ per year. Institutional ownership is also similar. Except for securities lending, bond funds are somewhat more likely than equity funds to engage in various sophisticated investment practices such as trading options and futures and shorting.

Appendix Table A1 gives formal definitions for the construction of all variables used in the analysis.

\section{Results}

We now present our main results. We start by showing that cash holdings play an economically significant role in how mutual funds manage their liquidity to meet inflows and outflows. We then study the determinants of cash holdings, showing that cash holdings are strongly related to asset liquidity and volatility of fund flows. It is worth noting that for much of the analysis, we are documenting endogenous relationships. Fund characteristics, investor behavior, and cash holdings are all jointly determined, and our results trace out the endogenous relationships between them. ${ }^{14}$

\section{A. Liquidity management through cash holdings}

We begin by examining Prediction 1 from Section II. We show that cash holdings play an important role in the way mutual funds manage inflows and outflows. In Table 2, we estimate regressions of the change in a fund's cash holdings over the last six months on the net flows it received during each of those six months:

$$
\Delta \operatorname{Cash}_{i, t-6 \rightarrow t}=\alpha_{o b j(i), t}+\beta_{0} \text { Flows }_{i, t}+\ldots+\beta_{5} \text { Flows }_{i, t-5}+\varepsilon_{i, t} .
$$

\footnotetext{
${ }^{13}$ Higher turnover of bond funds is in part due to a) bond maturities being treated as sales and b) trading in the tobe-announced market for agency MBS.

${ }^{14}$ In most cases, endogeneity should lead to coefficients that are smaller in magnitude. For instance, Chen, Goldstein, and Jiang (2010) argue that higher cash holdings should endogenously lower the volatility of fund flows because investors are less worried about fire sales. This should weaken the relationship between cash and fund flow volatility relative to the case where fund flow volatility is exogenous.
} 
Fund flows are winsorized at the $5^{\text {th }}$ and $95^{\text {th }}$ percentiles. In Appendix Table A2, we show that we obtain similar results winsorizing at the $1^{\text {st }}$ and $99^{\text {th }}$ percentiles. All specifications include Lipper objective code cross time (half-year) fixed effects, indicating that the results are not driven by relationships between flows and cash holdings in particular fund objectives.

We first examine the results for equity funds. In the first column of Table 2, the dependent variable is the change in cash holdings over the last six months as a fraction of net assets six months ago: $\Delta \operatorname{Cash}_{i, t-6 \rightarrow t} / T N A_{i, t-6}$. In the first column, the coefficient $\beta_{0}=0.23$ is large and highly statistically significant. Since flows are scaled by the same denominator - assets six months ago - as the dependent variable, the coefficients can be interpreted as dollars. Thus, $\beta_{0}=$ 0.23 indicates that a dollar of outflows during month $t$ decreases cash holdings by 23 cents. Similarly, a dollar of inflows increases cash holdings by 23 cents. The other 77 cents are met by transacting in the fund's holdings of equities. ${ }^{15}$ In untabulated results, when we run regressions separating inflows and outflows, we find that funds respond relatively symmetrically to them. This is consistent with the idea that funds care about the price pressure they exert on the underlying assets when both buying and selling.

The coefficient $\beta_{0}$ shows that an economically significant portion of flows is accommodated through cash holdings. Even though equities are quite liquid, and a month is a relatively long period, $23 \%$ of flows at a monthly horizon are accommodated through changes in cash holdings. Presumably, at higher frequencies (e.g., daily or weekly), cash plays an even more important role. The remaining coefficients show that the effect of fund flows on cash holdings declines over time. However, even fund flows in month $t-4$ still have a detectable effect on cash holdings at time $t$.

In the second column of Table 2, the dependent variable is the change in the fund's cashto-assets ratio:

$$
\Delta\left(\frac{\text { Cash }}{T N A}\right)_{i, t}=\left(\frac{\text { Cash }}{T N A}\right)_{i, t}-\left(\frac{\text { Cash }}{T N A}\right)_{i, t-6} .
$$

\footnotetext{
${ }^{15}$ These results are broadly consistent with Edelen (1999), who finds that a dollar of fund flows is associated with about 70 cents in trading activity.
} 
These regressions show that funds are not simply responding to flows by scaling their portfolios up and down. The overall composition of the portfolio is changing, becoming more cash-heavy when the fund receives inflows and less cash-heavy when the fund suffers outflows.

The coefficient $\beta_{0}=0.087$ is statistically and economically significant. Flows equal to $100 \%$ of assets increase the fund's cash-to-assets ratio by $8.7 \%$ (percentage points). For reference, the standard deviation of fund flows is $9 \%$. The coefficients here are likely to be biased down because of performance-flow relationships. If a fund has strong returns between month $t-6$ and month $t$, it is likely to receive inflows, but its cash-assets ratio at time $t$ will be depressed because high returns inflate assets at time $t$.

The last two columns of Table 2 report analogous results for bond funds. The coefficients are again large and statistically significant, and the economic magnitudes are larger. Specifically, in column (3), the coefficient $\beta_{0}=0.33$ indicates that one dollar of outflows in month $t$ decreases cash holdings by 33 cents. Similarly, in column (4), the coefficient $\beta_{0}=0.124$ indicates that flows equal to $100 \%$ of assets increase the fund's cash-to-assets ratio by $12.4 \%$ (percentage points). The larger magnitudes we find for bond funds are consistent with bonds being less liquid than equities. Because funds face a larger price impact trading in bonds, they accommodate a larger share of fund flows through changes in cash.

\section{B. Effect of asset liquidity and market illiquidity}

We next turn to Prediction 2 from Section II, examining how illiquidity affects funds' propensity to use cash to manage inflows and outflows in both the cross section and the time series. Panel A of Table 3 estimates specifications that allow cash management practices to differ across the cross section of funds based on the illiquidity of their assets. Specifically, we estimate:

$$
\begin{aligned}
\Delta \text { Cash }_{i, t-6 \rightarrow t} & =\alpha_{o b j(i), t}+\beta_{1} \text { Flows }_{i, t-2 \rightarrow t} \times \text { Illiq }_{i, t-6}+\beta_{2} \text { Flows }_{i, t-5 \rightarrow t-3} \times \text { Illiq }_{i, t-6} \\
& +\beta_{3} \text { Flows }_{i, t-2 \rightarrow t}+\beta_{4} \text { Flows }_{i, t-5 \rightarrow t-3}+\beta_{5} \text { Illiq }_{i, t-6}+\varepsilon_{i, t} .
\end{aligned}
$$

For compactness, we aggregate flows into quarters, i.e., those from month $t-5$ to $t-3$ and month $t$ 2 to $t .{ }^{16}$ We interact each of these quarterly flows with lagged values of holdings illiquidity.

\footnotetext{
${ }^{16}$ Interacting monthly flows with asset illiquidity generates somewhat stronger results for more recent fund flows.
} 
Thus, the specification asks: given the illiquidity of the holdings that a fund had two quarters ago, how did it respond to fund flows during the last two quarters?

For equity funds studied in the first two columns, illiquidity is measured as the square root version of the Amihud (2002) measure. In the first column, the dependent variable is the change in cash holdings over the last six months as a fraction of assets six months ago: $\Delta \operatorname{Cash}_{i, t-6 \rightarrow t} / T N A_{i, t-6}$. We standardize the illiquidity variables so that their coefficients can be interpreted as the effect of a one-standard deviation change in asset illiquidity. Again, all specifications have Lipper objective cross time fixed effects. The first column of Table 3 Panel A shows that for the average equity fund, one dollar of flows over months $t-2$ to $t$ changes cash holdings by $\beta_{3}=17$ cents. For a fund with assets one standard deviation more illiquid than the average fund, the same dollar of flows changes cash holdings by $\beta_{1}+\beta_{3}=21$ cents, a $21 \%$ larger effect. In the second column, the dependent variable is the change in the fund's cash-to-assets ratio. Once again, fund flows over the last three months have a larger effect on funds with more illiquid assets.

The last two columns of Table 3 Panel A report analogous results for bond funds. The magnitudes are similar. Column (3) shows that for the average bond fund, one dollar of flows over months $t$ - 2 to $t$ changes cash holdings by $\beta_{3}=15$ cents. For a fund with assets one standard deviation more illiquid than the average fund, the same dollar of flows changes cash holdings by $\beta_{1}+\beta_{3}=19$ cents, a $28 \%$ larger effect. However, in column (4), neither the coefficient on flows nor its interaction with market liquidity is statistically significant. We have less power to detect the effect of aggregate market liquidity in our bond sample because our sample size is significantly smaller.

In Panel B, we next turn to time variation in how funds manage their liquidity. When markets for the underlying securities are less liquid, funds should have a higher propensity to accommodate flows through changes in cash. Table 3 Panel B estimates specifications of the form:

$$
\begin{aligned}
\operatorname{cash}_{i, t-6 \rightarrow t} & =\alpha+\beta_{1} \text { Flows }_{i, t-2 \rightarrow t} \times \operatorname{LowAggLiq}_{i, t-2 \rightarrow t}+\beta_{2} \text { Flows }_{i, t-5 \rightarrow t-3} \times \operatorname{LowAgLLiq}_{i, t-5 \rightarrow t-3} \\
& +\beta_{3} \text { Flows }_{i, t-2 \rightarrow t}+\beta_{4} \text { Flows }_{i, t-5 \rightarrow t-3}+\beta_{5} \operatorname{LowAgLiq}_{i, t-2 \rightarrow t}+\beta_{6} \operatorname{LowAggLiq}_{i, t-5 \rightarrow t-3}+\varepsilon_{i, t}
\end{aligned}
$$


We measure aggregate market liquidity during separate quarters and then define the bottom tercile as periods of low aggregate market liquidity. For equity funds, our measure of aggregate market liquidity is the Pastor and Stambaugh (2003) measure. ${ }^{17}$ In the first column, the dependent variable is the change in cash holdings over the last six months as a fraction of assets six months ago: $\Delta \operatorname{Cash}_{i, t-6 \rightarrow t} / T N A_{i, t-6}$.

The first column of Table 3 Panel B shows that for the average half-year, one dollar of fund flows during months $t$-2 to $t$ changes cash balances by $\beta_{3}=16$ cents. When aggregate market liquidity is low, the same dollar of flows changes cash balances by $\beta_{1}+\beta_{3}=21$ cents, $30 \%$ more. In the second column, the dependent variable is the change in the fund's cash-toassets ratio. Here again, we see evidence that cash-to-assets ratios are more sensitive to fund flows when aggregate market liquidity is low.

The last two columns of Table 3 Panel B turn to bond funds. There is less agreement in the literature over the appropriate way to measure the liquidity of the aggregate bond market. We use the average of Dick-Nielsen, Feldhütter, and Lando (2012) lambda across all US-traded corporate bonds. ${ }^{18}$

Column (3) of Panel B shows estimates with larger magnitudes than we find for equity funds. One dollar of fund flows during months $t-2$ to $t$ changes cash balances by $\beta_{3}=10$ cents. When aggregate market liquidity is low, the same dollar of flows changes cash balances by $\beta_{1}+$ $\beta_{3}=22$ cents, or over $100 \%$ more. However, in column (4), neither the coefficient on flows nor its interaction with market liquidity is statistically significant. We have less power to detect the effect of aggregate market liquidity in our bond sample because our sample size is significantly smaller and, crucially for the tests in Table 3 Panel B, the time series dimension is shorter at eleven and a half years.

\footnotetext{
${ }^{17}$ We use the Pastor-Stambaugh measure rather than averaging the Amihud measure across stocks because changes in market capitalization mechanically induce changes in the Amihud measure. This means that time variation in the average Amihud measure does not necessarily reflect time variation in aggregate stock market liquidity.

18 We thank Peter Feldhütter for making the monthly time series available through his website http://feldhutter.com/USCorporateBondMarketLiquidity_updated.txt
} 


\section{Determinants of cash holdings}

Having shown that cash holdings play an important role in how mutual funds manage inflows and outflows, we next turn to the stock of cash holdings. We estimate regressions that seek to link fund cash holdings to liquidity transformation, as in Predictions 3 and 4 in Section II. Specifically, Table 4 reports the results of regressions of the form:

$$
\begin{aligned}
\frac{\text { Cash }_{i, t}}{T N A_{i, t}} & =\alpha+\beta_{1}^{\prime} \text { LiquidityTransformation }_{\mathbf{i}, \mathbf{t}}+\beta_{2}^{\prime} \text { Scale }_{\mathbf{i}, \mathrm{t}}+\beta_{3}^{\prime} \text { InvestorBehavior }_{\mathrm{i}, \mathrm{t}} \\
& +\beta_{4}^{\prime} \text { TradingPractices }_{\mathrm{i}, \mathrm{t}}+\varepsilon_{i, t} .
\end{aligned}
$$

We group the regressors into four categories. The first category consists of regressors related to liquidity transformation. As discussed in Section II, we include in this category the illiquidity of fund assets, the volatility of fund flows, and their interaction. The second category consists of regressors that capture economies of scale: the $(\log )$ size of the fund and the $(\log )$ size of the fund family. Our proxy for investor behavior is the fraction of the fund's assets that are in institutional share classes. Measures of trading practices include the fund's asset turnover and indicators for whether the fund uses various derivatives, borrows, lends out its securities, or engages in short sales.

The first two columns of Table 4 report the results for equity funds. All specifications include objective-time fixed effects with standard errors clustered at the fund family level. All continuous variables are standardized so that the coefficients can be interpreted as the effect of a one-standard deviation change in the independent variable.

The results indicate that funds that engage in more liquidity transformation hold more cash. Focusing on the second column, where we control for all explanatory variables simultaneously, a one-standard deviation increase in asset illiquidity increases the cash-to-assets ratio by 1.0 percentage points. Similarly, the volatility of fund flows comes in positive and significant. A one-standard deviation increase in flow volatility is associated with a 0.4 percentage points higher cash-to-assets ratio. Finally, the interaction between asset illiquidity and flow volatility is also positive and significant.

One way to see the importance of liquidity transformation in determining fund's cash holdings is to compare the predicted cash-to-assets ratio of two otherwise identical funds that 
have liquidity transformation measures one standard deviation below the mean and one standard deviation above the mean, respectively. Based on the estimates in column 2, that difference is 2.9 percentage points. This is about two-thirds of the median and almost $40 \%$ of the mean value of the cash-to-assets ratio, consistent with the idea that liquidity transformation is an important determinant of cash holdings.

Another way to see the importance of liquidity transformation is to compare the sensitivity of cash holdings to flow volatility across funds. Our results indicate that for funds with the most liquid assets $(\sigma($ Flows $)=-2$ standard deviations below the mean $)$, the total impact of flow volatility on cash holdings is $\beta_{\sigma(\text { Flows })}-2 \cdot \beta_{\sigma(\text { Flows }) \times \text { Illiq }}=0.35-2 \cdot 0.17=0.01$. That is, flow volatility has virtually no impact on cash holdings for funds with very liquid assets. For these funds, the frictionless null holds. They can trade without price impact and thus are not engaged in liquidity transformation and have no need for cash holdings that scale with flow volatility. However, the average fund is quite far from the frictionless null. Its cash holdings increase strongly with flow volatility.

Trading practices are also a significant determinant of cash holdings. Funds that engage in securities lending hold much more cash (6.6 percentage points) because they receive cash collateral when lending out securities. Similarly, funds that trade options and futures and that are engaged in short sales tend to hold more cash because they may need to pledge collateral.

Finally, our results provide mixed evidence of economies of scale in liquidity management. There is no evidence of economies of scale at the individual fund level. Why might this be the case? One reason is that highly correlated investor flows diminish the scope for scale economies. In particular, effective liquidity provision by mutual funds depends in part on gross inflows and outflows from different investors netting out. This is analogous to banks, where withdrawals from some depositors are met in part using incoming deposits from other depositors. This diversification across liquidity shocks to depositors allows banks to hold illiquid assets while providing depositors with demandable claims (Diamond and Dybvig, 1983). This diversification benefit increases with the number of investors in the fund but increases more slowly when investor flows are more correlated.

In the context of mutual funds, past returns are a natural public signal that results in correlated flows and thus diminished economies of scale. It is well known that net investor flows 
respond to past returns (e.g., Chevalier and Ellison, 1997; Sirri and Tufano, 1998). In particular, following poor fund returns, each individual investor is more likely to redeem shares from the fund. This reduces the fund's ability to diversify across investor flows and means that the fund is more likely to suffer net outflows. In untabulated results, we find strong evidence of this mechanism at work. The ratio of net flows faced to gross flows faced by a fund is strongly correlated with past returns.

We do find evidence of economies of scale at the fund family level rather than the fund level. A one-standard deviation increase in fund family total assets decreases the cash-to-assets ratio by 1.3 percentage points. As we discuss further below, these economies of scale do not appear to be driven by the fact that larger families tend to have alterative liquidity management tools like lines of credit, interfund lending programs (Agarwal and Zhao, 2015), or funds of funds (Bhattacharya, Lee, and Pool, 2013). Instead it appears that larger fund families have better back office infrastructure that allow them to economize on cash holdings, or that they have more scope to net offsetting trades across individual funds (Goncalves-Pinto and Schmidt, 2013).

In the last two columns of Table 4, we find broadly similar effects for bond mutual funds. Once again, the amount of liquidity transformation the fund engages in plays a key role. The coefficients on the volatility of fund flows and flow volatility interacted with asset illiquidity are both positive and significant. The magnitudes on these coefficients are larger than for equity funds. However, for bond funds, the coefficient on asset illiquidity does not come in significant. Because there is less agreement in the literature about the appropriate way to measure bond liquidity, Appendix Table A3 shows that we obtain similar results with other measures, including the Roll (1984) measure, the Amihud (2002) measure, and the imputed roundtrip cost.

The cash holdings we study in Table 4 are large in the aggregate and have grown rapidly over recent years. Fig. 1 shows the time series of holdings of both cash and cash substitutes. Holdings of cash and cash substitutes rise from $\$ 100$ billion in 1996 to $\$ 600$ billion in 2014. This is large as a fraction of total asset manager cash holdings, estimated by Pozsar (2013) to be approximately $\$ 2$ trillion. It is also large in comparison to corporate cash holdings, which also stand at approximately $\$ 2$ trillion.

The large cash holdings of mutual funds make clear that in the aggregate, liquidity transformation by asset managers relies heavily on liquidity provision by the banking and 
shadow banking systems. In order to provide their investors with liquid claims, asset managers must themselves hold large quantities of cash and cash substitutes. Moreover, these cash holdings come largely from the financial sector, not the government. In our data, over $80 \%$ of cash holdings are bank deposits and money market mutual fund shares, not Treasury securities. This presumably reflects an unwillingness of fund managers to pay the high liquidity premia associated with Treasuries when the banking and shadow banking systems can provide cheaper cash substitutes (e.g., Greenwood, Hanson, and Stein, 2015; Nagel, 2016; Sunderam, 2015).

\section{Robustness and alternative explanations}

Table 5 reports a battery of robustness exercises for our results on the determinants of cash holdings. Each row of the table reports the coefficients on our liquidity transformation variables in Eq. 9 estimated for both equity funds and bond funds. All specifications include the full suite of controls from Table 5 as well as objective-time fixed effects. Row (1) replicates our baseline results from columns (2) and (4) of Table 4.

The next five rows split the sample in various ways. Rows (2) and (3) split funds by size and show that the results are not driven by a large number of small funds that account for a small fraction of aggregate mutual fund assets. Rows (4) and (5) present the results before and after the financial crisis, and row (6) shows the results excluding money market mutual funds from our definition of cash. Across these rows, for equity funds, asset illiquidity always comes in positive and significant, flow volatility is positive and significant in all but one specification, and their interaction is positive and significant in three out of the six columns. For bond funds, the results are less consistent here, which is not surprising given the small size of the sample. Nonetheless, the volatility of fund flows is positive and significant in all but one specification, and the interaction of flow volatility and asset illiquidity is positive and significant in two out of the six columns.

The next several rows add controls that help to rule out alternative explanations. The first alternative is that, rather than measuring liquidity transformation, cash holdings reflect managers' expectations of risk and return. Specifically, fund managers may choose to hold more cash whenever they expect future returns to be low or risk to be high. ${ }^{19}$ If these expectations

\footnotetext{
${ }^{19}$ Huang (2013) provides evidence consistent with this story.
} 
correlate with our measures of liquidity transformation, they could explain the results in Table 4. Our inclusion of fund objective cross time fixed effects in Table 4 should absorb most such time variation in risk and expected returns. In rows (7), (8), and (9) of Table 5, we add future fund returns as controls in Eq. (9). Specifically, we analyze fund $i$ 's cash holdings at time $t$, controlling for returns between $t$ and $t+k$. The coefficients on our liquidity transformation variables, flow volatility, asset illiquidity, and their interaction, are not impacted, suggesting that they are not being driven by market timing considerations. ${ }^{20}$

Another alternative interpretation of the results in Table 4 is that cash holdings are driven by fund investment strategies, not by their liquidity transformation. Specifically, it could be the case that funds hold cash as dry powder to allow them to quickly take advantage of investment opportunities when they arise (Simutin, 2014). If the propensity to hold dry powder is related to the illiquidity of the assets the fund invests in, then the coefficient on asset illiquidity could be capturing the effects of dry powder as opposed to liquidity transformation. In rows (10) and (11) of Table 5, we augment our regression specification in Eq. (9) with proxies for funds that are more likely to want to hold dry powder. Our proxies are based on the idea that funds following such strategies are likely to make relatively large bets. Thus, we use the Herfindahl index of the fund's holdings and the portfolio share of the largest position. Adding these controls for dry powder has almost no effect on the estimated coefficients on the liquidity transformation variables: flow volatility, asset illiquidity, and their interaction. ${ }^{21}$ This suggests that our results are in fact capturing the association between cash holdings and liquidity transformation.

A third alternative explanation is that cash holdings are driven by managerial characteristics like risk aversion or skill. If some fund managers are more risk averse than others, and these managers tend to hold more illiquid assets, this could explain the results in Table 4. Similarly, more skilled managers may choose to hold more cash in order to quickly take advantage of new investment opportunities when they arise. In row (12) of Table 5, we control for a variety of managerial characteristics that have been used in the literature as proxies for

\footnotetext{
${ }^{20}$ For equity funds, the coefficients on future returns provide some evidence of market timing. Funds hold more cash when future returns are going to be low.

${ }^{21}$ The coefficients on these dry powder proxy variables come in positive and statistically significant as well. A onestandard deviation increase in holdings $\mathrm{HHI}$ is associated with $0.97 \%$ higher cash-to-assets ratio for equity funds and $1.44 \%$ higher cash-to-assets ratio for bond funds. The share of the largest position has a similar effect.
} 
ability or risk aversion, including total industry experience, tenure with the current fund, possession of a certified financial analyst (CFA) credential, and ACT score. ${ }^{22}$ We report the results for the sample of observations for which we have all explanatory variables. The sample size is reduced by about a third for equity funds and a quarter for bond funds. For both equity funds and bond funds, controlling for these managerial characteristics has virtually no impact on the liquidity transformation variables. Overall, our results are very stable across these specifications aimed at ruling out alternative explanations by adding controls.

\section{E. Matched pairs}

One may still worry that our controls are imperfect and that the results in Tables 4 and 5 are driven by explanations other than liquidity transformation. The ideal experiment to isolate the effect of liquidity transformation would hold fixed fund managers' information and investment opportunity set while varying how much liquidity investors demanded from the fund.

This suggests comparing the portfolio decisions one manager makes for two funds with the same investment objective but different flow volatilities. Variable annuities funds provide a laboratory to approximate this ideal experiment. Variable annuities funds are mutual funds sold as part of an insurance product. These funds are regulated and structured just like regular mutual funds under the Investment Company Act of 1940. Indeed, for many variable annuity funds, there is also a regular mutual fund with the same manager and mandate. For example, American Century VP Income \& Growth Fund is a variable annuity fund in our data, and American Century Income \& Growth Fund is the corresponding regular mutual fund. The two funds have the same investment goal and investment strategy and are managed by the same team of three portfolio managers. The only difference between the two is that the variable annuity fund "only offers shares through insurance company separate accounts."23

Because they are sold as a part of an insurance product, variable annuity funds face less flow volatility than regular mutual funds. In CRSP Mutual Fund Database, the annualized

\footnotetext{
${ }^{22}$ Chevalier and Ellison (1999) and Greenwood and Nagel (2009), among others, use SAT scores as a proxy for ability. We use the average ACT rather than SAT score of students admitted to manager's undergraduate institution because in our data the ACT score is available for a larger number of institutions. Using SAT scores generates similar results.

${ }^{23}$ Fund prospectus on Form N-1A: https://www.sec.gov/Archives/edgar/data/814680/000081468016000172/acvp2016485bpos.htm
} 
volatility of monthly fund flows of variable annuity funds is $4.6 \%$ lower than that of comparable regular funds. ${ }^{24}$ This effect represents $29 \%$ of the mean $(16.0 \%)$ and $61 \%$ of the median $(7.5 \%)$ volatility.

To study the effects of these differences in flow volatility on cash holdings, we construct a sample of fund pairs with the same investment objective, where one fund is a variable annuity fund, and its paired fund is a regular mutual fund managed by the same portfolio manager. We are able to find 187 pairs, with each pair having on average 8 semi-annual observations. ${ }^{25}$

Table 6 examines cash holdings in this matched sample. The table regresses the cash-toassets ratio of a dummy variable for variable annuity funds, while clustering the standard errors by adviser to account for any correlation across funds managed by the same adviser. In the first column, the coefficient on the variable annuity dummy indicates that variable annuity funds have 0.66 percentage points lower cash-to-assets ratio than matched regular funds. The magnitude of the effect is sizable compared to the average cash-to-assets of regular funds of $5.27 \%$. Columns (2) and (3) analyze the equity and bond funds separately. Though the bond fund sample is too small for statistical significance, the point estimates are similar for bond and equity funds. Finally, columns (4) and (5) split the equity funds in our sample by their asset illiquidity. ${ }^{26}$ The difference in cash holdings between variable annuity and regular funds is negative and significant for both groups. As one would expect, however, the magnitude is larger in funds with illiquid assets. Overall, the results of Table 6 strongly support the idea that differences in liquidity transformation drive differences in cash holdings across funds.

In Appendix Table A4, we take another approach to addressing alternative explanations, instrumenting for asset liquidity and flow volatility with the fund's Lipper objective code and its age, respectively. The idea is that funds' asset holdings are constrained by their objective: high-

\footnotetext{
${ }^{24}$ For each fund, we first calculate the volatility of fund flows during each year in the 2009-2015 period when variable annuity funds are included in CRSP. We exclude funds with less than $\$ 10 \mathrm{M}$ in lagged net assets and winsorize flow volatility at the $1^{\text {st }}$ and $99^{\text {th }}$ percentiles. The effect of variable annuity is then estimated from a regression of flow volatility on the variable annuity dummy, while controlling for objective-time fixed effects and fund size.

${ }^{25} \mathrm{~A}$ key constraint on finding matched pairs is that many variable annuity and regular funds have different reporting cycles. Almost all variable annuity funds have their fiscal year end in December, while many regular mutual funds have fiscal year ends in October and November. Such differences in reporting cycles prevent us from being able to observe the fund's cash holdings at the same point in time and force us to discard potential matches.

${ }^{26} \mathrm{We}$ split fund pairs based on the asset liquidity of the regular fund. We do not have enough bond fund pairs to split them by their liquidity.
} 
yield funds must hold high-yield bonds. Thus, variation in liquidity driven by objective is not an endogenous choice. Similarly, the volatility of fund flows declines with age, because investors have less to learn about a fund with a long history (Chevalier and Ellison, 1997; Berk and Green, 2004). ${ }^{27}$ The appendix table shows that our main results go through using this IV strategy.

\section{Internalizing Price Impact}

\section{A. Fund-level results}

We next examine Prediction 5 from Section II, asking whether mutual fund cash holdings are large enough to fully mitigate the price impact externalities created by the liquidity transformation that funds engage in. In this section, we provide suggestive evidence that they are not. We run two types of tests. The first is based on the idea that monopolists internalize their price impact. As discussed in Section II, this suggests that funds that own a larger fraction of the securities they invest in should internalize more of their price impact and as a result should have higher cash-to-assets ratios.

To examine this prediction, we estimate regressions similar to those in Eq. (9) but augment them with measures of the fund's share of the securities it owns. Specifically, for each security that the fund holds, we first calculate the fund's share of either aggregate mutual fund holdings of that security or of the security's outstanding amount. We then calculate the valueweighted average across all securities in the fund's portfolio. Finally, we standardize the resulting variables so that their coefficients represent the effect of a one-standard deviation change.

Columns (1) and (2) of Table 7 report the results for equity funds. In column 1, the coefficient on the fund's share of the securities it owns as a fraction of aggregate mutual fund holdings is positive and statistically significant. It is also economically meaningful - a one standard deviation higher share of aggregate holdings increases the cash-to-assets ratio by 0.8 percentage points. In column (2), we look at the fund's share of the securities it owns as a

\footnotetext{
${ }^{27}$ Objective code is a somewhat limited instrument because it is time invariant, but it helps rule out alternative explanations based on market timing and managerial risk aversion. Because it could still be the case that certain objectives are more amenable to dry powder strategies, we make sure to directly control for dry powder considerations using holdings HHI. This makes it more likely that the exclusion restriction - a fund's objective affects cash holdings only through the illiquidity of the fund's assets - is satisfied.
} 
fraction of the securities' outstanding amounts. We obtain similar results, though the economic magnitude is smaller.

Our second test of price impact internalization is based on the idea that fund families may at least partially internalize price impact across different funds in the family. Thus, if a fund holds assets that are also held by other funds in the same family, then the fund may be more likely to internalize the price impact of its trading on those funds than on funds outside the fund family. This suggests that funds should hold more cash when there is greater overlap in their holdings with other funds within the fund family. Furthermore, we might expect this effect to be stronger for larger funds. By their sheer size, larger funds might have to dump more assets on the market, resulting in larger price impact than smaller funds (for the same percentage of asset fund flows and asset sales).

To examine this prediction, we estimate panel regressions similar to those in Eq. (9) but augment with them a measure of holdings overlap. For each security that the fund holds, we calculate the share of this security in the aggregate holdings of all other funds within the family. We then calculate the value-weighted average of this measure across all securities in the fund's portfolio. If none of the fund's securities are held by other funds in the same family, the holdings overlap measure will be zero. The more of the fund's securities are held by other funds in the same family, the greater will be the holdings overlap measure. ${ }^{28}$

Column (3) of Table 7 reports the results for equity funds. The coefficient on overlap itself is positive but not statistically significant. However, the coefficient on the interaction of overlap and fund size is positive and statistically significant. This indicates that large funds that have significant overlap in holdings with other funds in the same family hold more cash. This is consistent with the idea that such funds try to mitigate the price impact externalities they would otherwise impose on other funds in the family.

Columns (4), (5) and (6) of Table 7 report the results for bond funds. In columns (4) and (5), the coefficients on the fund's share of the securities it owns are positive but not significant. In column (6), the coefficient on overlap is large, positive, and statistically significant. For bond funds, a one-standard deviation increase in holdings overlap with other family funds is associated

\footnotetext{
${ }^{28}$ In untabulated regressions, we find that holdings overlap is driven by manager overlap. If two funds in the same family share a manager, they are more likely to have similar holdings.
} 
with a 0.9 percentage points higher cash-to-assets ratio. The coefficient on the interaction of holdings overlap, and fund size is not statistically significant, however.

\section{B. Position-level results}

One concern that arises with the results in Table 7 is that they may simply reflect differences in the characteristics of assets holdings across funds rather than differences in internalization of price impact. For instance, funds that hold a large share of the securities they own might invest primarily in small, illiquid securities. In this case, our finding that such funds hold more cash might simply reflect the fact that our measures of liquidity are imperfect.

We can address this concern using position-level data in Table 8. Specifically, we form a security-fund-time panel and run regressions analogous to those in Table 7. The dependent variable for security $s$ held by fund $f$ at time $t$ is the cash-to-assets ratio of fund $f$ at time $t$. The independent variable of interest will be either the fund $f$ 's share of the securities it owns at time $t$ or fund $f$ 's holdings overlap with other funds in the same family at time $t$. Thus, we are effectively running fund-time level regressions within our security-fund-time level dataset.

The key difference between Tables 7 and 8 is that we can include security fixed effects in Table 8 . Thus, the results in Table 8 look at variation within security, absorbing variation across securities in the average characteristics of the funds holding that security. Put differently, the results compare two funds that hold the same security, one of which holds a higher share of the securities it owns that the other. To make the results in Table 8 analogous to those in Table 7, we weight the regressions by the portfolio share of each security. Standard errors are clustered by fund-time.

Table 8 shows that we obtain very similar results to Table 7 for equity funds. The share a fund holds of the equities it owns is positively and significantly related to cash holdings, as is the overlap of the fund holdings with other funds in the family (for larger funds).

For bond funds, the results in Table 8 are a bit stronger than those in Table 7 . The share a fund holds of the bonds it owns is positively and significantly related to cash holdings. The overlap of the fund holdings with other funds in the family is also positively and significantly related to cash holdings. 
Overall, the evidence in this section is consistent with the idea that funds do not fully internalize the price impact of their trading on one another. They suggest that in a counterfactual world in which a single fund owned one hundred percent of the securities it invested in, cash holdings would be substantially higher in order to mitigate price impact associated with liquidity transformation. Similarly, in a counterfactual world where all funds were in the same fund family, cash holdings would be substantially higher.

\section{Alternative Liquidity Management Tools}

In our analysis throughout the paper, we have assumed that cash is the only tool funds have for liquidity management. In this section, we discuss four alternative liquidity management tools that funds have at their disposal. Two of these alternative tools, lines of credit and in-kind redemption options, may be useful for liquidity management in times of stress. The other two, within-family lending programs and redemption fees, may be useful in normal times as well as times of stress. The key takeaway of our analysis is that although funds do have access to alternative liquidity management tools, they appear to use them very little in practice. In equilibrium, cash is still strongly related with liquidity transformation despite the existence of alternative liquidity management tools.

\section{A. Lines of credit and in-kind redemption options}

We start by analyzing the two liquidity management tools that may be useful in times of stress: lines of credit and in-kind redemption options. Lines of credit can be used to meet redemption requests without having to sell illiquid assets. They are generally arranged at the fund family level and made available to all funds within the family. Individual funds pay their pro-rata share of any commitment fees and pay interest based on the fund's actual borrowings.

We first examine whether fund families typically have credit lines at all. We read annual reports on form N-CSR and prospectuses on form 485BPOS to collect information on credit lines for the top 150 mutual fund families as of the end of 2014. These fund families account for more than $97 \%$ of aggregate mutual fund assets in the CRSP Mutual Fund Database. About 60\% of families in the sample report having a line of credit. Because larger families are more likely to have a line of credit, at least $80 \%$ of total mutual fund assets is held by families with lines of credit. Lines of credit are generally small relative to the assets of the fund family. The median credit facility is less than $0.44 \%$ of the fund family assets. 
Our primary data source, SEC form N-SAR, also gives us a window into drawdowns on lines of credit. Funds report whether, at any point during the six-month reporting period, they had bank loans exceeding $1 \%$ of TNA. Fig. 2 reports the fraction of funds that had bank loans exceeding $1 \%$ of TNA as a function of fund flows. The figure shows that usage is generally quite low. About 5\% (7\%) of equity (bond) funds have bank loans exceed 1\% of TNA during a typical reporting period. Large outflows are associated with a higher probability of drawing on a line of credit. But even funds experiencing very large outflows are unlikely to draw down their line of credit. The five percent of observations with the largest outflows suffer average outflows of more than $20 \%$ of assets. Yet, even for these funds, the probability of having bank loans exceed $1 \%$ of TNA is only $15 \%$.

Thus, although most funds do have access to a line of credit, utilization rates are low. This suggests that funds view lines of credit as an imperfect substitute for cash holdings. This is consistent with Acharya, Almeida, and Campello (2013), who argue that nonfinancial firms with greater aggregate liquidity risk should use cash rather than lines of credit. The idea is that because banks pool risks across nonfinancial firms, credit lines are less likely to be a reliable source of liquidity if there is an aggregate liquidity shock, when many firms are likely to draw their lines simultaneously. Thus, for firms more exposed to aggregate liquidity shocks, cash is a safer option. In our case, mutual funds are quite exposed to aggregate liquidity shocks because fund flows are strongly correlated with aggregate market returns. This implies that mutual funds should prefer cash to credit lines as a source of liquidity.

Redeeming in kind - giving investors a pro-rata share of the fund's portfolio instead of cash - is another way for mutual funds to offer less liquidity to investors in times of stress. In normal times, in-kind redemptions are typically both legally and mechanically challenging for mutual funds. ${ }^{29}$ However, in times of stress, funds may utilize the option.

We collect data from SEC filings to get a rough estimate of the quantitative importance of in-kind redemptions. Since retail funds are extremely unlikely to redeem in-kind, we focus on

\footnotetext{
${ }^{29}$ Most funds irrevocably commit themselves under Rule 18f-1 to redeem all retail investors in cash. Funds can still redeem in-kind requests from institutional investors, but even the latter might find it costly, if not impossible, to hold certain types of assets. Repurchase agreements and Eurodollar deposits, for example, are over-the-counter contracts that cannot be transferred to multiple investors. There can be restrictions on the funds' ability to transfer syndicated loan participations, as these can require approval from the borrower.
} 
institutional funds with at least $\$ 1$ billion in assets. For each fund, we choose the quarter the fund experienced its largest dollar outflow and discard the other quarters. We then examine the 50 fund-quarter observations with the largest outflows. Out of these 50 observations, only 3 had inkind redemptions. In value terms, our observations suffered combined net outflows of $\$ 123.3$ billion. Out of this, $\$ 7.7$ billion, or about $6 \%$, was redeemed in-kind. These results confirm that in-kind redemptions are rare and play a limited role as an alternative liquidity management tool.

\section{B. Interfund lending programs and redemption fees}

We next analyze the two liquidity management tools that may be useful in both normal times and times of stress: interfund lending programs, in which funds borrow from other funds in the same family, and redemption fees. Interfund lending is typically forbidden. ${ }^{30}$ However, fund families can ask the SEC for exemptive relief if such borrowing is "appropriate in the public interest and consistent with the protection of investors." Agarwal and Zhao (2015) provide more background on interfund lending programs and study the determinants and consequences of such programs. In particular, they find that as of 2013, only thirty fund families had set up interfund lending programs.

In Table 9, we ask whether having an interfund lending program weakens the relationship between cash holdings and liquidity transformation. We run regressions like Eq. (9), splitting the sample into funds with interfund lending programs and funds without them. Columns 1 and 2 report the results for equity funds. The results are broadly similar across the sample split. Although the coefficient on flow volatility for funds with interfund lending programs is not statistically significant, the coefficients on asset illiquidity and its interaction with flow volatility are. Moreover, their magnitudes are actually larger than for funds without an interfund lending program. Columns 5 and 6 report the results of an analogous sample split for bond funds. The sample of bond funds that have an interfund lending program is very small. As a result, none of the liquidity transformation coefficients are statistically significant. Their magnitudes, however, are comparable to the sample of funds without access to an interfund lending program. Overall, the results are consistent with the idea that liquidity transformation plays an equally important role in determining cash holdings, whether a fund has an interfund lending program or not. This

\footnotetext{
${ }^{30}$ Section 17(a) of the Investment Company Act of 1940 prohibits transactions between affiliates, while section 21(b) prohibits funds from lending to any entity under common control.
} 
suggests that interfund lending programs do not strongly substitute for cash holdings as liquidity management tools.

Finally, we examine redemption fees. Funds that impose redemption fees and deferred sales load charges effectively offer less liquidity to their investors. Only $26 \%$ of our equity fund observations and $30 \%$ of our bond fund observations have such fees. Are they an effective substitute for liquidity management through cash holdings? In Table 9, we also report the results of estimating Eq. (9) when we split the sample into funds with redemption fees versus funds without such fees. We once again get broadly similar results for both groups of funds, suggesting that even funds that impose redemption fees must rely on cash holdings as their primary liquidity management tool.

Overall, the analysis in this section suggests that funds appear to use their alternative liquidity management tools very little in practice. Cash is the main tool mutual funds use to manage their liquidity. These results validate our insight that cash holdings are a good measure of a fund's liquidity transformation activities.

\section{Conclusion}

We study the cash management strategies of equity and bond mutual funds to shed light on liquidity transformation by asset managers. Our analysis highlights three key features of this liquidity transformation. First, cash management practices suggest it is significant. Mutual funds accommodate a substantial fraction of fund flows through changes in cash holdings as opposed to trading in portfolio securities. For equity funds, a $\$ 1$ of fund outflows in month $t$ decreases cash holdings by 23 cents. For bond funds, the same $\$ 1$ of outflows decreases cash holdings by 33 cents.

Second, the fact that mutual funds accommodate fund flows through changes in cash holdings indicates that liquidity transformation in asset management is highly dependent on liquidity provision by the traditional banking and shadow banking sectors. In order to provide liquidity to end investors, mutual funds must hold substantial amounts of cash, bank deposits, and money market mutual fund shares.

Third, despite their size, cash holdings of mutual funds are not large enough to completely mitigate price impact externalities created by the liquidity transformation that mutual 
funds engage in. Our evidence suggests that funds do not fully internalize the effects that providing investors with daily liquidity have on the prices of the underlying securities. 


\section{References}

Acharya, Viral, and Lasse Pedersen, 2005, Asset Pricing with Liquidity Risk, Journal of Financial Economics 77, 375-410.

Acharya, Viral, Heitor Almeida, and Murillo Campello, 2013, Aggregate Risk and the Choice between Cash and Lines of Credit, Journal of Finance 68, 2059-2116.

Agarwal, Vikas, and Haibei Zhao, 2015, Interfund lending in mutual fund families: Role of internal capital markets.

Almazan, Andres, Keith C. Brown, Murray Carlson, and David A. Chapman, 2004, Why Constrain Your Mutual Fund Manager? Journal of Financial Economics 73, 289-321.

Amihud, Yakov, 2002, Illiquidity and Stock Returns: Cross-Section and Time Series Effects, Journal of Financial Markets 5, 31-56.

Amihud, Yakov, and Haim Mendelson, 1986, Liquidity and Stock Returns, Financial Analysts Journal 42, 43-48.

Bao, Jack, Jun Pan, and Jiang Wang, 2011, The Illiquidity of Corporate Bonds, Journal of Finance 66, 911-946.

Bates, Thomas W., Kathleen M, Kahle, and Rene Stulz, 2009, Why Do U.S. Firms Hold so Much More Cash than They Used to? Journal of Finance 64, 1985-2021.

Berger, Allen and Christa Bouwman, 2009, Bank liquidity creation, Review of Financial Studies 22(9), 3779-3837.

Berk, Jonathan B. and Richard C. Green, 2004, Mutual fund flows and performance in rational markets, Journal of Political Economy 112, 1269-95.

Bhattacharya, Utpal, Jung H Lee, and Veronika K Pool, 2013, Conflicting family values in mutual fund families, The Journal of Finance 68, 173-200.

Chen, Qi, Itay Goldstein, and Wei Jiang, 2010, Payoff Complementarities and Financial Fragility: Evidence from Mutual Fund Outflows, Journal of Financial Economics 97, 239-262.

Chernenko, Sergey and Adi Sunderam, 2014, Frictions in Shadow Banking: Evidence from the Lending Behavior of Money Market Funds, Review of Financial Studies, 27 (6): 1717 1750 .

Chevalier, Judith and Glenn Ellison, 1997, Risk Taking by Mutual Funds as a Response to Incentives, Journal of Political Economy 105, 1167-1200.

Chevalier, Judith and Glenn Ellison, 1999, Are Some Mutual Fund Managers Better Than Others? Cross-Sectional Patterns in Behavior and Performance, Journal of Finance 54(3), 875-899. 
Chordia, Tarun, Richard Roll, and Avanidhar Subrahmanyam, 2001, Market Liquidity and Trading Activity, Journal of Finance 56, 501-530.

Cornett, Marcia, Jamie McNutt, Philip Strahan, and Hassan Tehranian, 2011, Liquidity risk management and credit supply in the financial crisis, Journal of Financial Economics 101(2), 297-312.

Coval, Joshua, and Erik Stafford, 2007, Asset Fire Sales (and Purchases) in Equity Markets, Journal of Financial Economics 86, 479-512.

Diamond, Douglas, and Philip Dybvig, 1983, Bank Runs, Deposit Insurance, and Liquidity, Journal of Political Economy 91, 401-419.

Dick-Nielsen, Jens, Peter Feldhütter, and David Lando, 2012, Corporate Bond Liquidity Before and After the Onset of the Subprime Crisis, Journal of Financial Economics 103, 471492.

Edelen, Roger M, 1999, Investor flows and the assessed performance of open-end mutual funds, Journal of Financial Economics 53, 439-466.

Ellul, Andrew, Chotibhak Jotikasthira, and Christian Lundblad, 2011, Regulatory Pressure and Fire Sales in the Corporate Bond Market, Journal of Financial Economics 101, 596-620.

Feldhütter, Peter, 2012, The same bond at different prices: Identifying search frictions and selling pressures, Review of Financial Studies 25, 1155-1206.

Feroli, Michael, Anil Kashyap, Kermit L. Schoenholtz, and Hyun Song Shin, 2014, Market Tantrums and Monetary Policy, U.S. Monetary Policy Forum Report No.8, Initiative on Global Markets, University of Chicago Booth School of Business.

Financial Stability Oversight Committee, 2014 Annual Report.

Goldstein, Itay, Hao Jiang, and David Ng, 2015, Investor Flows and Fragility in Corporate Bond Funds, Unpublished working paper.

Goncalves-Pinto and Breno Schmidt, 2013, Co-Insurance in Mutual Fund Families, Unpublished working paper.

Gorton, Gary and Andrew Metrick, 2010, Regulating the Shadow Banking System, Brookings Papers on Economic Activity.

Gorton, Gary and Andrew Metrick, 2012, Securitized banking and the run on repo, Journal of Financial Economics, Volume 104, Issue 3, Pages 425-451.

Gorton, Gary, and George Penacchi, 1990, Financial Intermediaries and Liquidity Creation, Journal of Finance 45, 49-72.

Greenwood, Robin, and Stefan Nagel, 2009, Inexperienced Investors and Bubbles, Journal of Financial Economics 93, 239-258. 
Greenwood, Robin, and David Thesmar, 2011, Stock Price Fragility, Journal of Financial Economics 102, 471-490.

Greenwood, Robin, Samuel G. Hanson, and Jeremy C. Stein, 2015, A Comparative-Advantage Approach to Government Debt Maturity, Journal of Finance, forthcoming.

Hanouna, Paul, Jon Novak, Tim Riley, and Christof Stahel, 2015, Liquidity and Flows of U.S. Mutual Funds, Division of Economic and Risk Analysis White Paper, U.S. Securities and Exchange Commission.

Huang, Jiekun, 2013, Dynamic Liquidity Preferences of Mutual Funds, working paper.

Independent Directors Council, 2016, IDC Comments on the SEC's Liquidity Risk Management Proposal.

International Monetary Fund, 2015, Global Financial Stability Report: Navigating Monetary Policy Challenges and Managing Risks.

Investment Company Institute, 2016, ICI Comments on the SEC's Liquidity Risk Management Proposal.

Kacpercyzk, Marcin and Philipp Schnabl, 2010, When safe proved risky, Journal of Economic Perspectives, 24(1), 29-50.

Kacpercyzk, Marcin and Philipp Schnabl, 2013, How safe are money market funds?, Quarterly Journal of Economics 128(3), 1073-1122.

Krishnamurthy, Arvind, and Annette Vissing-Jorgensen, 2015, The Impact of Treasury Supply on Financial Sector Lending and Stability, Journal of Financial Economics.

Krishnamurthy, Arvind, Stefan Nagel, and Dmitry Orlov, 2014, Sizing Up Repo, Journal of Finance, 69: 2381-2417.

Longstaff, Francis A, 2004, The Flight-to-Liquidity Premium in U.S. Treasury Bond Prices, Journal of Business 77, 511-526.

Merrill, Craig B., Taylor D. Nadauld, Shane M. Sherlund, and Rene Stulz, 2012, Did Capital Requirements and Fair Value Accounting Spark Fire Sales in Distressed Mortgage Backed Securities? NBER Working Paper No. 18270.

Moreira, Alan and Alexi Savov, 2016, The Macroeconomics of Shadow Banking, Journal of Finance, forthcoming.

Nagel, Stefan, 2016, The Liquidity Premium of Near-Money Assets, Quarterly Journal of Economics, forthcoming.

Pastor, Lubos, and Robert F. Stambaugh, 2003, Liquidity Risk and Expected Stock Returns, Journal of Political Economy 111, 642-685.

Pozsar, Zoltan, 2013, Institutional cash pools and the Triffin dilemma of the US banking system, Financial Markets, Institutions \& Instruments 22, 283-318. 
Roll, Richard, 1984, A Simple Implicit Measure of the Effective Bid-Ask Spread in an Efficient Market, The Journal of Finance 39, , 1127-1139.

Schmidt, Lawrence, Allan Timmerman, and Russ Wermers, 2016, Runs on Money Market Mutual Funds, American Economic Review, forthcoming.

Securities and Exchange Commission, 2015. Open-End Fund Liquidity Risk Management Programs, Release No. 33-9922.

Shleifer, Andrei, and Robert W. Vishny, 1992, Liquidation Values and Debt Capacity: A Market Equilibrium Approach, Journal of Finance 47, 1343-1366.

Shleifer, Andrei, and Robert W. Vishny, 1997, The Limits of Arbitrage, The Journal of Finance $52,35-55$.

Simutin, Mikhail, 2014, Cash Holdings and Mutual Fund Performance, Review of Finance 18, 1425-1464.

Sirri, Erik, and Peter Tufano, 1998, Costly Search and Mutual Fund Flows, Journal of Finance 53, 1589-1622.

Stein, Jeremy, 2012, Monetary Policy as Financial-Stability Regulation, Quarterly Journal of Economics 127, 57-95.

Sunderam, Adi, 2015, Money Creation and the Shadow Banking System, Review of Financial Studies 28, 939-977.

Wang, Jeffrey, 2015, Asset Managers and Financial Instability: Evidence of Run Behavior and Run Incentives in Corporate Bond Funds, Harvard College Senior thesis.

Yan, Xuemin (Sterling), 2006, The Determinants and Implications of Mutual Fund Cash Holdings, Financial Management 35, 67-91.

Zeng, Yao, 2015, A Dynamic Theory of Mutual Fund Runs and Liquidity Management, Unpublished working paper. 
Figure 1

Aggregate cash holdings of equity and bond mutual funds

Aggregate cash holdings of actively managed open-end equity and bond mutual funds reporting on the semi-annual form N-SAR, matched to the CRSP Mutual Fund Database. The sample excludes index, money market, and municipal funds, variable annuities, ETFs, and funds of funds. Cash is cash, repurchase agreements, and short-term debt securities. Cash and substitutes is the sum of cash, repurchase agreements, short-term debt securities, and money market fund shares. See Appendix Table A1 for more details on measurement of cash substitutes.

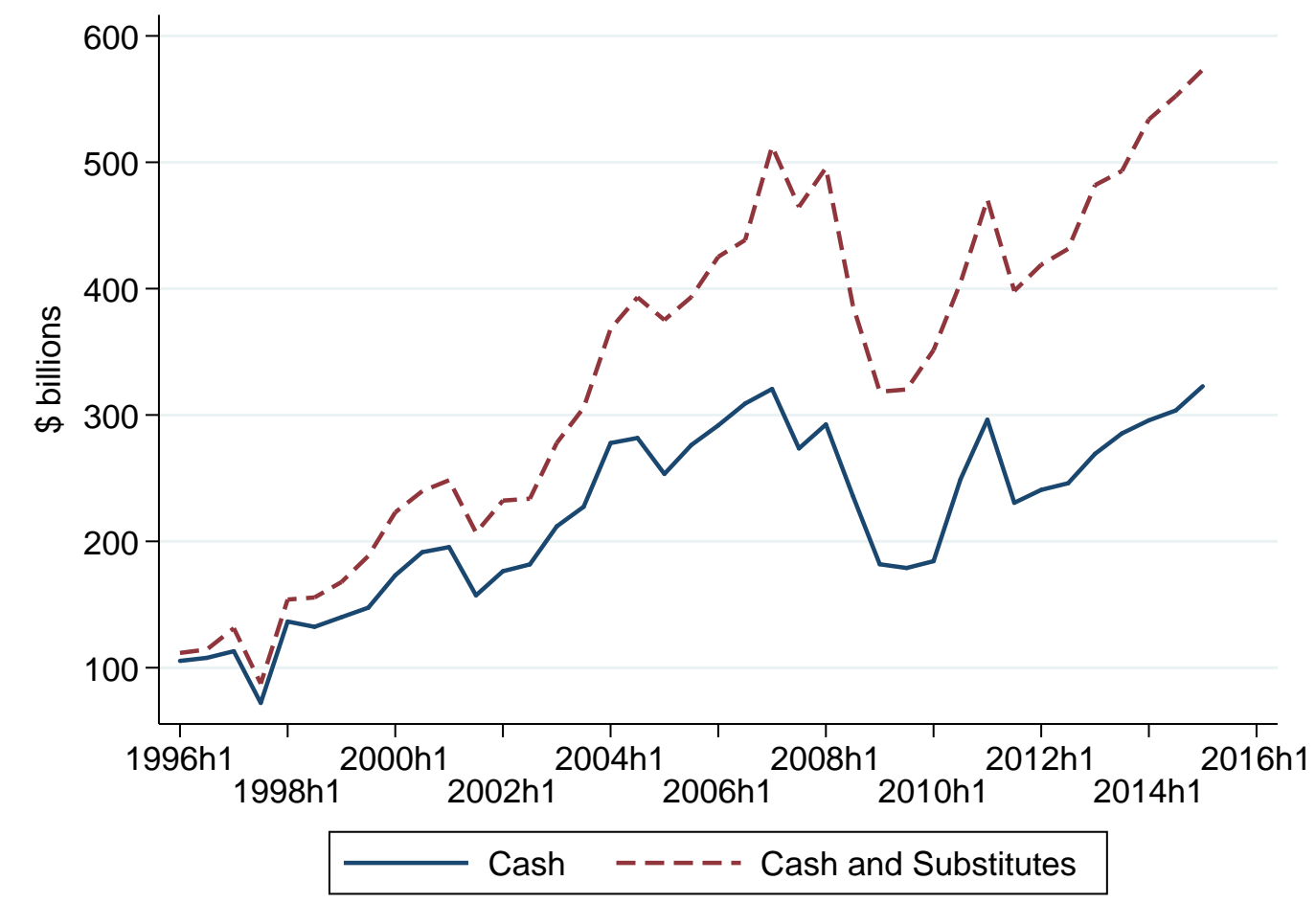


Figure 2

Utilization of lines of credit

This figure shows the relationship between fund flows and utilization of lines of credit. Funds report whether at any point during the semi-annual reporting period they had bank loans exceed $1 \%$ of TNA. We sort observations into twenty bins based on their cumulative semi-annual fund flows scaled by lagged assets. For each bin we then calculate the average value of fund flows as well as the fraction of observations with bank loans exceeding 1\% of TNA. Each dot represents a single bin that accounts for five percent of the sample.

(a) Equity funds

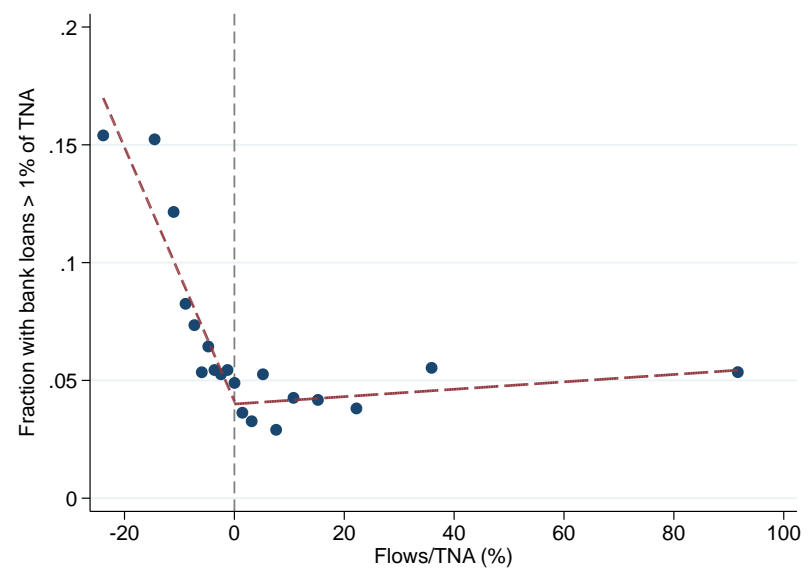

(b) Bond funds

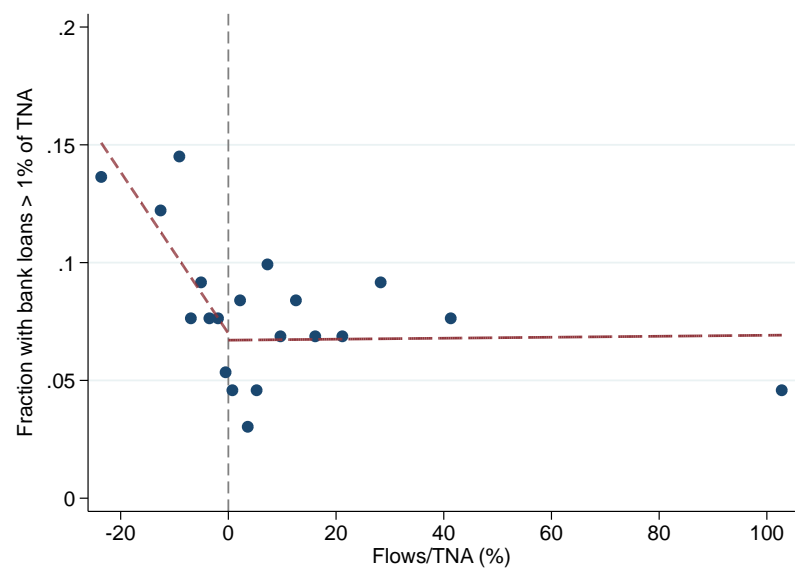


Table 1

\section{Summary statistics}

This table reports summary statistics for the sample of mutual funds studied in the paper. Actively managed equity and bond open-end funds reporting on the semi-annual form N-SAR are matched to the CRSP Mutual Fund Database. The sample excludes money market funds, index funds, ETFs, variable annuities, and funds with less than $\$ 100$ million in TNA (measured in 2012 dollars). The sample of equity funds is limited to domestic equity funds. The sample of bond funds is limited to funds with Lipper objectives A, BBB, HY, IID, MSI, SII that invest at least $50 \%$ of their portfolio in corporate bonds. The sample period for equity funds is $2003-2014$. The sample period for bond funds is January 2004-June 2012. Illiq is Amihud (2002) for equity funds and Dick-Nielsen, Feldhütter, and Lando (2012) for bond funds. Share of Agg Holdings is the weighted-average of the fund's holdings of each portfolio security relative to aggregate holdings by all mutual funds in CRSP. Share of Outstanding is the weighted-average of the fund's holdings of each portfolio security relative to the security's outstanding amount. Holdings Overlap measures overlap in holdings with other funds within the same family. Size is $\ln (T N A)$. Family size is $\ln \left(\right.$ familyTNA). Flows $s_{j \rightarrow k}$ is net flows from month $j$ to $k$, scaled by net assets six months ago. Fund flows are winsorized at the 5 th and 95 th percentiles. Turnover is the minimum of purchases and sales, divided by the monthly average size of the portfolio. $\sigma$ (Flows) is the standard deviation of monthly net flows during the semi-annual reporting period. Sec lending/Shorting/Options/Other are indicators for funds that engage in securities lending/shorting/trading of options and other derivatives/and other investment practices specified in question 70 of form N-SAR.

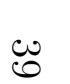

\begin{tabular}{|c|c|c|c|c|c|c|c|c|c|c|c|c|}
\hline & \multicolumn{6}{|c|}{ Equity funds } & \multicolumn{6}{|c|}{ Bond funds } \\
\hline & \multirow[b]{2}{*}{$N$} & \multirow[b]{2}{*}{ Mean } & \multirow[b]{2}{*}{$\mathrm{SD}$} & \multicolumn{3}{|c|}{ Percentile } & \multirow[b]{2}{*}{$N$} & \multirow[b]{2}{*}{ Mean } & \multirow[b]{2}{*}{$\mathrm{SD}$} & \multicolumn{3}{|c|}{ Percentile } \\
\hline & & & & 25 & 50 & 75 & & & & 25 & 50 & 75 \\
\hline$T N A$ & 22,427 & 2064.81 & 5785.14 & 228.59 & 580.14 & 1554.87 & 2,648 & 1435.07 & 2537.71 & 233.76 & 521.29 & 1346.28 \\
\hline Size & 22,427 & 6.52 & 1.33 & 5.43 & 6.36 & 7.35 & 2,648 & 6.41 & 1.23 & 5.45 & 6.26 & 7.21 \\
\hline Family size & 22,427 & 10.57 & 2.14 & 9.12 & 10.74 & 12.01 & 2,648 & 10.55 & 1.72 & 9.54 & 10.76 & 11.56 \\
\hline Cash/Assets & 22,427 & 7.48 & 8.47 & 1.94 & 4.36 & 9.52 & 2,648 & 7.89 & 7.53 & 2.55 & 5.28 & 10.76 \\
\hline$\Delta$ Cash/Assets & 22,427 & 0.67 & 6.60 & -1.66 & 0.13 & 2.31 & 2,578 & 0.77 & 7.68 & -2.54 & 0.12 & 2.94 \\
\hline$\Delta($ Cash $/$ Assets $)$ & 22,427 & -0.14 & 5.20 & -1.87 & -0.04 & 1.64 & 2,578 & -0.19 & 6.07 & -2.70 & -0.12 & 2.24 \\
\hline Flows $_{t-5 \rightarrow t-3}$ & 22,427 & 2.73 & 13.84 & -3.55 & -0.65 & 4.53 & 2,648 & 4.64 & 14.75 & -2.38 & 1.32 & 7.25 \\
\hline Flows $_{t-2 \rightarrow t}$ & 22,427 & 2.36 & 12.16 & -3.47 & -0.44 & 4.76 & 2,648 & 4.61 & 14.51 & -2.18 & 1.44 & 7.06 \\
\hline Illiq & 22,427 & 0.02 & 0.02 & 0.01 & 0.01 & 0.03 & 2,648 & -0.21 & 0.18 & -0.34 & -0.25 & -0.12 \\
\hline Institutional share & 22,427 & 29.19 & 37.19 & 0.00 & 7.48 & 56.96 & 2,648 & 31.28 & 37.71 & 0.00 & 10.01 & 60.61 \\
\hline Turnover & 22,427 & 56.10 & 50.08 & 22.00 & 41.00 & 74.00 & 2,648 & 73.48 & 79.15 & 27.00 & 48.00 & 85.00 \\
\hline$\sigma($ Flows $)$ & 22,427 & 8.87 & 11.22 & 2.27 & 4.93 & 10.72 & 2,648 & 10.14 & 11.76 & 3.01 & 6.05 & 12.47 \\
\hline Sec lending & 22,427 & 0.50 & 0.50 & 0.00 & 0.00 & 1.00 & 2,648 & 0.41 & 0.49 & 0.00 & 0.00 & 1.00 \\
\hline Shorting & 22,427 & 0.02 & 0.16 & 0.00 & 0.00 & 0.00 & 2,648 & 0.04 & 0.19 & 0.00 & 0.00 & 0.00 \\
\hline Options & 22,427 & 0.03 & 0.06 & 0.00 & 0.00 & 0.00 & 2,648 & 0.05 & 0.10 & 0.00 & 0.00 & 0.12 \\
\hline Other practices & 22,427 & 0.36 & 0.18 & 0.25 & 0.38 & 0.50 & 2,648 & 0.43 & 0.15 & 0.38 & 0.50 & 0.50 \\
\hline Holdings HHI & 22,427 & 0.02 & 0.01 & 0.01 & 0.02 & 0.03 & 2,648 & 0.01 & 0.01 & 0.01 & 0.01 & 0.01 \\
\hline Top share & 22,427 & 5.00 & 4.74 & 2.85 & 4.17 & 5.84 & 2,648 & 3.54 & 3.23 & 1.63 & 2.33 & 4.11 \\
\hline Share of Agg Holdings & 22,427 & 2.36 & 3.84 & 0.25 & 0.81 & 2.69 & 2,648 & 11.35 & 10.88 & 3.87 & 7.50 & 14.66 \\
\hline Share of Outstanding & 22,427 & 0.45 & 0.72 & 0.05 & 0.16 & 0.50 & 2,648 & 1.45 & 1.92 & 0.34 & 0.72 & 1.57 \\
\hline Holdings Overlap & 22,427 & 0.37 & 0.48 & 0.07 & 0.25 & 0.48 & 2,648 & 0.15 & 0.33 & 0.01 & 0.05 & 0.15 \\
\hline
\end{tabular}


Table 2

Flow management through cash holdings

This table reports the results of regressions of changes in cash holdings on fund flows:

$$
\Delta \operatorname{Cash}_{i, t-6 \rightarrow t}=\alpha_{o b j(i), t}+\sum_{s=0}^{5} \beta_{s} \text { Flows }_{i, t-s}+\varepsilon_{i, t} .
$$

In columns (1) and (3), the dependent variable is the change in cash over a six-month period, scaled by assets six months ago. In columns (2) and (4), the dependent variable is the change in the cash-to-assets ratio over a six-month period. The independent variables are monthly net fund flows, scaled by net assets six months ago. All specifications include objective-time fixed effects. The sample perioid is 2003-2014 for equity funds and January 2004-June 2012 for bond funds. Standard errors are adjusted for clustering by time. $*, * *$, and $* * *$ indicate statistical significance at $10 \%, 5 \%$, and $1 \%$.

\begin{tabular}{|c|c|c|c|c|}
\hline & \multicolumn{2}{|c|}{ Equity funds } & \multicolumn{2}{|c|}{ Bond funds } \\
\hline & $\frac{\Delta C a s h}{T N A}$ & $\Delta\left(\frac{C a s h}{T N A}\right)$ & $\frac{\Delta \text { Cash }}{\text { TNA }}$ & $\Delta\left(\frac{C a s h}{T N A}\right)$ \\
\hline & (1) & $(2)$ & $(3)$ & $(4)$ \\
\hline \multirow{2}{*}{ Flows $_{i, t}$} & $0.230^{* * *}$ & $0.087^{* * *}$ & $0.329^{* * *}$ & $0.124^{* *}$ \\
\hline & $(0.029)$ & $(0.019)$ & $(0.075)$ & $(0.052)$ \\
\hline \multirow{2}{*}{ Flows $_{i, t-1}$} & $0.208^{* * *}$ & 0.047 & 0.085 & -0.018 \\
\hline & $(0.035)$ & $(0.030)$ & $(0.050)$ & $(0.041)$ \\
\hline \multirow[t]{2}{*}{ Flows $_{i, t-2}$} & $0.171^{* * *}$ & 0.037 & $0.213^{* *}$ & 0.070 \\
\hline & $(0.036)$ & $(0.029)$ & $(0.083)$ & $(0.061)$ \\
\hline \multirow[t]{2}{*}{ Flows $_{i, t-3}$} & $0.136^{* * *}$ & -0.003 & 0.055 & -0.066 \\
\hline & $(0.025)$ & $(0.019)$ & $(0.074)$ & $(0.076)$ \\
\hline \multirow{2}{*}{ Flows $_{i, t-4}$} & $0.074^{* * *}$ & -0.025 & 0.010 & -0.080 \\
\hline & $(0.026)$ & $(0.015)$ & $(0.071)$ & $(0.078)$ \\
\hline \multirow[t]{2}{*}{ Flows $_{i, t-5}$} & -0.039 & $-0.119^{* * *}$ & $0.146^{*}$ & -0.016 \\
\hline & $(0.029)$ & $(0.022)$ & $(0.070)$ & $(0.049)$ \\
\hline$N$ & 19,212 & 19,212 & 2,515 & 2,515 \\
\hline Adjusted $R^{2}$ & 0.136 & 0.024 & 0.099 & 0.012 \\
\hline
\end{tabular}


Table 3

Interactions with asset and market illiquidity

This table reports the result of regressions of changes in cash holdings on fund flows interacted with (a) the fund's asset illiquidity and (b) aggregate market illiquidity:

$$
\begin{aligned}
\Delta \text { Cash }_{i, t-6 \rightarrow t} & =\alpha_{o b j(i), t}+\beta_{1} \text { Flows }_{i, t-2 \rightarrow t}+\beta_{2} \text { Flows }_{i, t-2 \rightarrow t} \times \text { Illiq }_{i, t-6} \\
& +\beta_{3} \text { Flows }_{i, t-5 \rightarrow t-3}+\beta_{4} \text { Flows }_{i, t-5 \rightarrow t-3} \times \text { Illiq }_{i, t-6}+\beta_{5} \text { Illiq }_{i, t-6}+\varepsilon_{i, t} .
\end{aligned}
$$

In columns (1) and (3), the dependent variable is the change in cash over a six-month period, scaled by assets six months ago. In columns (2) and (4), the dependent variable is the change in the cash-to-assets ratio over a six-month period. Asset illiquidity is measured as of the beginning of the six-month period and is standardized so that the coefficients on illiquidity and its interactions represent the effect of a one-standard deviation change in illiquidity. All specifications include objective-time fixed effects. The sample perioid is 2003-2014 for equity funds and January 2004-June 2012 for bond funds. Standard errors are adjusted for clustering by time. *, **, and

\begin{tabular}{|c|c|c|c|c|}
\hline & \multicolumn{2}{|c|}{ Equity funds } & \multicolumn{2}{|c|}{ Bond funds } \\
\hline & $\frac{\Delta \text { Cash }}{T N A}$ & $\Delta\left(\frac{C a s h}{T N A}\right)$ & $\frac{\Delta \text { Cash }}{T N A}$ & $\Delta\left(\frac{C a s h}{T N A}\right)$ \\
\hline & $(1)$ & $(2)$ & $(3)$ & $(4)$ \\
\hline \multicolumn{5}{|c|}{ Panel A: Asset illiquidity } \\
\hline \multirow[t]{2}{*}{ Flows $_{i, t-2 \rightarrow t}$} & $0.171^{* * *}$ & $0.043^{* * *}$ & $0.146^{* * *}$ & 0.030 \\
\hline & $(0.010)$ & $(0.006)$ & $(0.030)$ & $(0.019)$ \\
\hline \multirow[t]{2}{*}{ Flows $_{i, t-2 \rightarrow t} \times$ Illiq $_{i, t-6}$} & $0.036^{* * *}$ & $0.016^{*}$ & $0.041^{*}$ & 0.015 \\
\hline & $(0.012)$ & $(0.009)$ & $(0.020)$ & $(0.016)$ \\
\hline \multirow{2}{*}{ Flows $_{i, t-5 \rightarrow t-3}$} & $0.082^{* * *}$ & $-0.027^{* * *}$ & $0.143^{* * *}$ & -0.010 \\
\hline & $(0.013)$ & $(0.007)$ & $(0.035)$ & $(0.038)$ \\
\hline \multirow[t]{2}{*}{ Flows $_{i, t-5 \rightarrow t-3} \times$ Illiq $_{i, t-6}$} & 0.016 & -0.005 & -0.041 & -0.016 \\
\hline & $(0.010)$ & $(0.008)$ & $(0.037)$ & $(0.025)$ \\
\hline \multirow[t]{2}{*}{ Illiq $_{i, t-6}$} & 0.096 & -0.063 & 0.398 & 0.157 \\
\hline & $(0.126)$ & $(0.079)$ & $(0.357)$ & $(0.306)$ \\
\hline$N$ & 19,212 & 19,212 & 2,515 & 2,515 \\
\hline Adjusted $R^{2}$ & 0.143 & 0.022 & 0.109 & 0.010 \\
\hline \multicolumn{5}{|c|}{ Panel B: Market illiquidity } \\
\hline \multirow[t]{2}{*}{ Flows $_{i, t-2 \rightarrow t}$} & $0.161^{* * *}$ & $0.037^{* * *}$ & $0.104^{* *}$ & 0.011 \\
\hline & $(0.013)$ & $(0.007)$ & $(0.039)$ & $(0.022)$ \\
\hline \multirow{2}{*}{ Flows $_{i, t-2 \rightarrow t} \times$ Low Agg Liq $q_{t-2 \rightarrow t}$} & $0.049^{* *}$ & $0.024^{*}$ & $0.123^{* *}$ & 0.056 \\
\hline & $(0.022)$ & $(0.013)$ & $(0.058)$ & $(0.039)$ \\
\hline \multirow[t]{2}{*}{ Flows $_{i, t-5 \rightarrow t-3}$} & $0.082^{* * *}$ & $-0.029^{* * *}$ & $0.209^{* * *}$ & $0.056^{* *}$ \\
\hline & $(0.015)$ & $(0.006)$ & $(0.039)$ & $(0.025)$ \\
\hline \multirow{2}{*}{ Flows $_{i, t-5 \rightarrow t-3} \times$ Low Agg Liq $q_{t-5 \rightarrow t-3}$} & 0.003 & 0.001 & $-0.183^{* *}$ & $-0.180^{* *}$ \\
\hline & $(0.027)$ & $(0.017)$ & $(0.066)$ & $(0.072)$ \\
\hline$N$ & 19,212 & 19,212 & 2,515 & 2,515 \\
\hline Adjusted $R^{2}$ & 0.139 & 0.022 & 0.113 & 0.021 \\
\hline
\end{tabular}
$* * *$ indicate statistical significance at $10 \%, 5 \%$, and $1 \%$. 


\section{Table 4}

\section{Level of cash holdings}

This table reports the results of regressions of the cash-to-assets ratio on fund characteristics:

$$
\begin{aligned}
\left(\frac{\text { Cash }}{T N A}\right)_{i, t} & =\alpha_{o b j(i), t}+\beta_{\mathbf{1}}^{\prime} \text { LiquidityTransformation }_{i, t}+\beta_{\mathbf{2}}^{\prime} \text { Scale }_{i, t} \\
& +\beta_{\mathbf{3}}^{\prime} \text { InvestorBehavior }_{i, t}+\beta_{\mathbf{4}}^{\prime} \text { TradingPractices }_{i, t}+\varepsilon_{i, t}
\end{aligned}
$$

All specifications include objective-time fixed effects. For equity funds, Illiq is the square-root version of Amihud (2002). For bond funds, Illiq is the Dick-Nielsen, Feldhütter, and Lando (2012) measure. All continuous variables are standardized so that their coefficients represent the effect of a one-standard deviation change in each variable. Standard errors are adjusted for clustering by fund family. $*, * *$, and $* * *$ indicate statistical significance at $10 \%, 5 \%$, and $1 \%$.

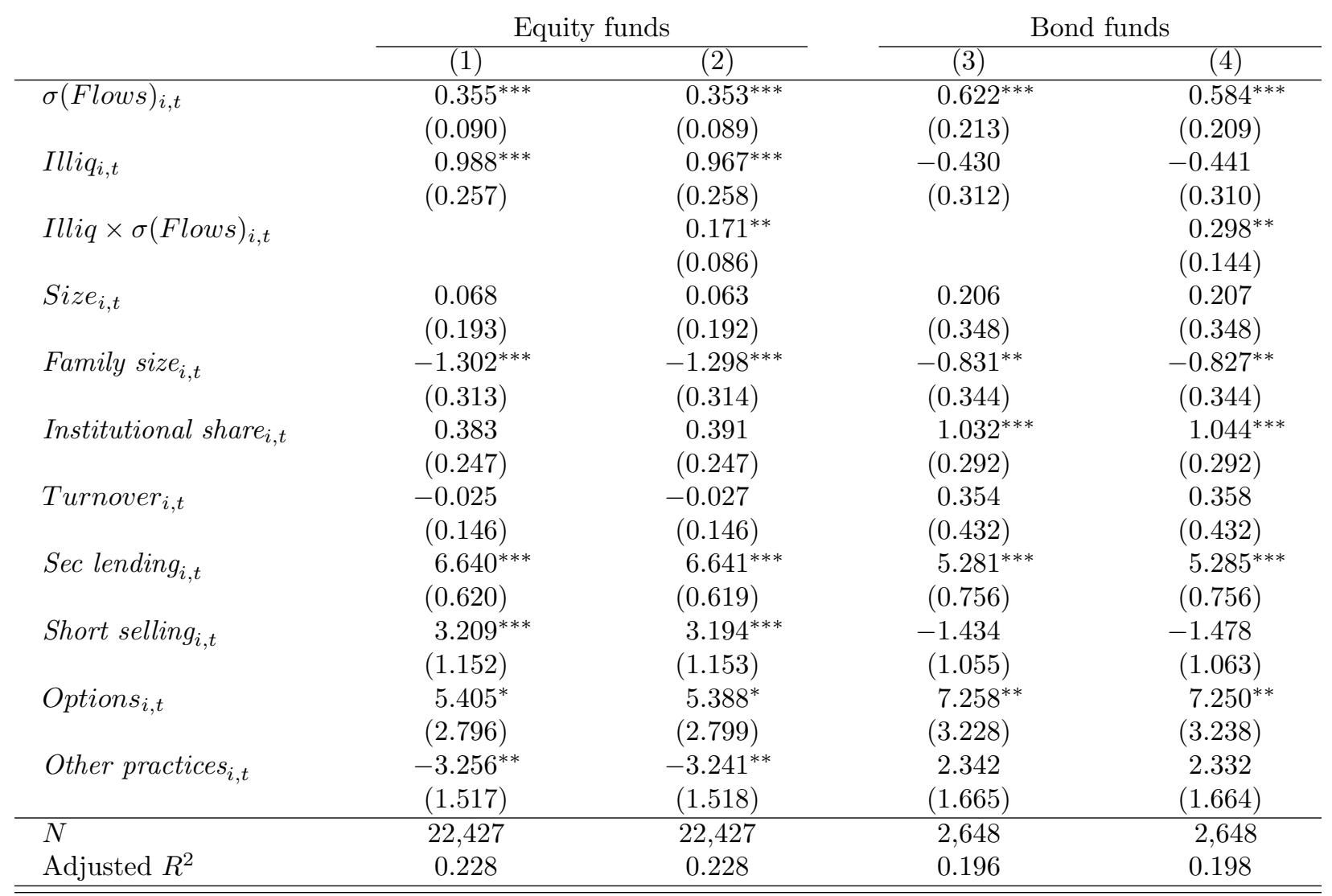




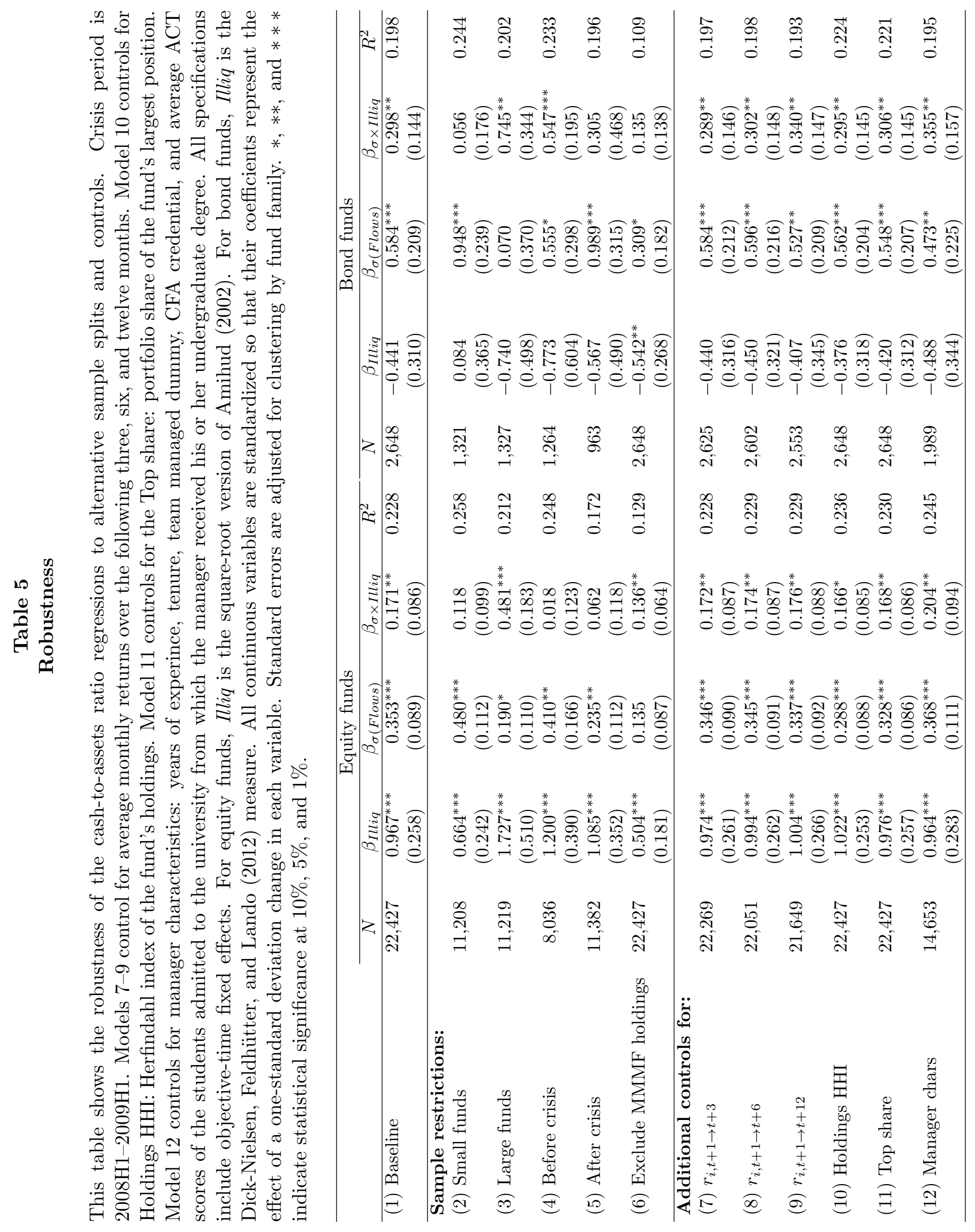




\section{Table 6}

\section{Cash holdings of matched variable annuity and regular mutual funds}

This table reports the regressions of the cash-to-assets ratio on the variable annuity dummy in the matched sample of variable annuity and regular mutual funds:

$$
\left(\frac{\text { Cash }}{T N A}\right)_{i, t}=\alpha+\beta \text { Variable annuity }_{i, t}+\varepsilon_{i, t} .
$$

The matched sample consists of 187 fund pairs in which both funds have the same objective, are advised by the same firm, and have the same semi-annual reporting period. Funds with TNA smaller than $\$ 10$ million are excluded. The sample period is 2003-2014. Columns (4) and (5) split funds based on their asset illiquidity. Specifically, we split funds into two equal-sized groups based on the asset illiquidity of the regular mutual fund. The sample is limited to equity funds, with asset illiquidity measured as the square root of Amihud (2002). Cash holdings are adjusted for cash collateral received for securities on loan. Standard errors are adjusted for clustering by adviser. *, $* *$, and $* * *$ indicate statistical significance at $10 \%, 5 \%$, and $1 \%$.

\begin{tabular}{|c|c|c|c|c|c|}
\hline & \multirow[b]{3}{*}{ (1) } & \multicolumn{2}{|c|}{ By fund type } & \multicolumn{2}{|c|}{ By asset liquidity } \\
\hline & & Equity & Bond & Liquid & Illiquid \\
\hline & & $(2)$ & $(3)$ & $(4)$ & $(5)$ \\
\hline \multirow[t]{2}{*}{ Variable annuity } & $-0.657^{* *}$ & $-0.725^{* *}$ & -0.235 & $-0.688^{* *}$ & $-0.913^{* *}$ \\
\hline & $(0.264)$ & $(0.293)$ & $(0.529)$ & $(0.316)$ & $(0.412)$ \\
\hline \multirow[t]{2}{*}{ Constant } & $5.272^{* * *}$ & $4.601^{* * *}$ & $9.401^{* *}$ & $4.125^{* * *}$ & $5.056^{* * *}$ \\
\hline & $(0.753)$ & $(0.417)$ & $(3.670)$ & $(0.467)$ & $(0.621)$ \\
\hline$N$ & 3,002 & 2,582 & 420 & 1,160 & 1,162 \\
\hline$R^{2}$ & 0.002 & 0.006 & 0.000 & 0.008 & 0.008 \\
\hline
\end{tabular}


Table 7

Internalizing price impact: Fund level analysis

This table reports the results of regressions of the cash-to-assets ratio on fund characteristics:

$$
\left(\frac{\text { Cash }}{T N A}\right)_{i, t}=\alpha_{o b j(i), t}+\beta \text { Internalize }_{i, t}+\gamma^{\prime} \mathbf{X}_{i, t}+\varepsilon_{i, t} .
$$

All specifications include objective-time fixed effects and the full suite of controls included in Table 4. For equity funds, Illiq is the square-root version of Amihud (2002). For bond funds, Illiq is the Dick-Nielsen, Feldhütter, and Lando (2012) measure. All continuous variables are standardized so that their coefficients represent the effect of a one-standard deviation change in each variable. Standard errors are adjusted for clustering by fund family. *, **, and $* * *$ indicate statistical significance at $10 \%, 5 \%$, and $1 \%$.

\begin{tabular}{|c|c|c|c|c|c|c|}
\hline & \multicolumn{3}{|c|}{ Equity funds } & \multicolumn{3}{|c|}{ Bond funds } \\
\hline & (1) & $(2)$ & (3) & (4) & $(5)$ & (6) \\
\hline Share of agg holdings $s_{i, t}$ & $\begin{array}{l}0.795^{* * *} \\
(0.230)\end{array}$ & & & $\begin{array}{c}0.116 \\
(0.463)\end{array}$ & & \\
\hline Share of outstanding $g_{i, t}$ & & $\begin{array}{c}0.467^{* *} \\
(0.219)\end{array}$ & & & $\begin{array}{c}0.212 \\
(0.433)\end{array}$ & \\
\hline Overlap $_{i, t}$ & & & $\begin{array}{c}0.129 \\
(0.298)\end{array}$ & & & $\begin{array}{l}0.878^{* * *} \\
(0.319)\end{array}$ \\
\hline Overlap $\times S i z e_{i, t}$ & & & $\begin{array}{l}0.311^{* *} \\
(0.152)\end{array}$ & & & $\begin{array}{c}-0.024 \\
(0.147)\end{array}$ \\
\hline$\sigma(\text { Flows })_{i, t}$ & $\begin{array}{l}0.331^{* * *} \\
(0.089)\end{array}$ & $\begin{array}{l}0.344^{* * *} \\
(0.088)\end{array}$ & $\begin{array}{l}0.349^{* * *} \\
(0.089)\end{array}$ & $\begin{array}{l}0.585^{* * *} \\
(0.209)\end{array}$ & $\begin{array}{l}0.588^{* * *} \\
(0.208)\end{array}$ & $\begin{array}{c}0.532^{* *} \\
(0.207)\end{array}$ \\
\hline Illiq $_{i, t}$ & $\begin{array}{l}0.531^{* *} \\
(0.252)\end{array}$ & $\begin{array}{l}0.775^{* * *} \\
(0.252)\end{array}$ & $\begin{array}{c}0.993^{* * *} \\
(0.259)\end{array}$ & $\begin{array}{c}-0.461 \\
(0.319)\end{array}$ & $\begin{array}{c}-0.469 \\
(0.313)\end{array}$ & $\begin{array}{r}-0.560^{*} \\
(0.330)\end{array}$ \\
\hline Illiq $\times \sigma(\text { Flows })_{i, t}$ & $\begin{array}{c}0.180^{* *} \\
(0.086)\end{array}$ & $\begin{array}{c}0.192^{* *} \\
(0.085)\end{array}$ & $\begin{array}{c}0.161^{*} \\
(0.086)\end{array}$ & $\begin{array}{c}0.299^{* *} \\
(0.145)\end{array}$ & $\begin{array}{c}0.301^{* *} \\
(0.145)\end{array}$ & $\begin{array}{c}0.289^{* *} \\
(0.140)\end{array}$ \\
\hline$N$ & 22,427 & 22,427 & 22,427 & 2,648 & 2,648 & 2,648 \\
\hline Adjusted $R^{2}$ & 0.232 & 0.229 & 0.230 & 0.198 & 0.198 & 0.209 \\
\hline
\end{tabular}


Table 8

\section{Internalizing price impact: Position level analysis}

This table reports the results of the regressions of the cash-to-assets ratio on fund characteristics:

$$
\left(\frac{C a s h}{T N A}\right)_{i, s, t}=\alpha_{s, t}+\alpha_{o b j(i), t}+\beta \text { Internalize }_{i, t}+\gamma^{\prime} \mathbf{X}_{i, t}+\varepsilon_{i, s, t},
$$

where $i$ indexes funds, $s$ indexes securities, and $t$ indexes time. All specifications include securitytime and objective-time fixed effects, as well as the full suite of controls included in Table 4. For equity funds, Illiq is the square-root version of Amihud (2002). For bond funds, Illiq is the DickNielsen, Feldhütter, and Lando (2012) measure. All continuous variables are standardized so that their coefficients represent the effect of a one-standard deviation change in each variable. Standard errors are adjusted for clustering by fund-time. $*, * *$, and $* * *$ indicate statistical significance at $10 \%, 5 \%$, and $1 \%$.

\begin{tabular}{|c|c|c|c|c|c|c|}
\hline \multirow{3}{*}{ Share of agg holdings $s_{i, t}$} & \multicolumn{3}{|c|}{ Equity funds } & \multicolumn{3}{|c|}{ Bond funds } \\
\hline & (1) & $(2)$ & (3) & $(4)$ & $(5)$ & (6) \\
\hline & $\begin{array}{l}0.488^{* * *} \\
(0.079)\end{array}$ & & & $\begin{array}{c}0.499^{* *} \\
(0.206)\end{array}$ & & \\
\hline Share of outstanding $i_{i, t}$ & & $\begin{array}{l}0.199^{* * *} \\
(0.070)\end{array}$ & & & $\begin{array}{c}0.300^{*} \\
(0.179)\end{array}$ & \\
\hline Overlap $_{i, t}$ & & & $\begin{array}{c}0.053 \\
(0.061)\end{array}$ & & & $\begin{array}{l}0.764^{* * *} \\
(0.245)\end{array}$ \\
\hline Overlap $\times$ Size $_{i, t}$ & & & $\begin{array}{l}0.242^{* * *} \\
(0.052)\end{array}$ & & & $\begin{array}{c}-0.122 \\
(0.106)\end{array}$ \\
\hline Illiq $_{i, t}$ & $\begin{array}{l}0.545^{\text {*** }} \\
(0.115)\end{array}$ & $\begin{array}{l}0.709^{* * *} \\
(0.120)\end{array}$ & $\begin{array}{l}0.809^{* * *} \\
(0.112)\end{array}$ & $\begin{array}{c}-0.357 \\
(0.252)\end{array}$ & $\begin{array}{c}-0.300 \\
(0.252)\end{array}$ & $\begin{array}{c}-0.318 \\
(0.252)\end{array}$ \\
\hline$\sigma(\text { Flows })_{i, t}$ & $\begin{array}{l}0.357^{* * *} \\
(0.061)\end{array}$ & $\begin{array}{l}0.361^{* * *} \\
(0.061)\end{array}$ & $\begin{array}{l}0.359^{* * *} \\
(0.061)\end{array}$ & $\begin{array}{l}0.544^{* * *} \\
(0.148)\end{array}$ & $\begin{array}{l}0.547^{* * *} \\
(0.148)\end{array}$ & $\begin{array}{l}0.504^{* * *} \\
(0.147)\end{array}$ \\
\hline Illiq $\times \sigma(\text { Flows })_{i, t}$ & $\begin{array}{c}0.080 \\
(0.066)\end{array}$ & $\begin{array}{c}0.077 \\
(0.066)\end{array}$ & $\begin{array}{c}0.055 \\
(0.066)\end{array}$ & $\begin{array}{l}0.349^{* * *} \\
(0.120)\end{array}$ & $\begin{array}{l}0.352^{* * *} \\
(0.121)\end{array}$ & $\begin{array}{l}0.354^{* * *} \\
(0.123)\end{array}$ \\
\hline$S i z e_{i, t}$ & $\begin{array}{c}-0.251^{* * *} \\
(0.071)\end{array}$ & $\begin{array}{r}-0.140^{*} \\
(0.076)\end{array}$ & $\begin{array}{c}-0.077 \\
(0.058)\end{array}$ & $\begin{array}{c}-0.081 \\
(0.190)\end{array}$ & $\begin{array}{c}-0.015 \\
(0.218)\end{array}$ & $\begin{array}{c}0.172 \\
(0.144)\end{array}$ \\
\hline Family size $_{i, t}$ & $\begin{array}{c}-1.269^{* * *} \\
(0.067)\end{array}$ & $\begin{array}{c}-1.295^{* * *} \\
(0.066)\end{array}$ & $\begin{array}{c}-1.292^{* * *} \\
(0.067)\end{array}$ & $\begin{array}{c}-0.851^{* * *} \\
(0.154)\end{array}$ & $\begin{array}{c}-0.890^{* * *} \\
(0.156)\end{array}$ & $\begin{array}{c}-0.975^{* * *} \\
(0.152)\end{array}$ \\
\hline Institutional share $_{i, t}$ & $\begin{array}{l}0.396^{* * *} \\
(0.056)\end{array}$ & $\begin{array}{l}0.379^{* * *} \\
(0.056)\end{array}$ & $\begin{array}{l}0.367^{* * *} \\
(0.056)\end{array}$ & $\begin{array}{l}0.963^{* * *} \\
(0.139)\end{array}$ & $\begin{array}{l}0.941^{* * *} \\
(0.136)\end{array}$ & $\begin{array}{l}0.863^{* * *} \\
(0.134)\end{array}$ \\
\hline Turnover $_{i, t}$ & $\begin{array}{c}0.009 \\
(0.061)\end{array}$ & $\begin{array}{c}0.003 \\
(0.061)\end{array}$ & $\begin{array}{c}-0.013 \\
(0.060)\end{array}$ & $\begin{array}{r}0.295^{*} \\
(0.168)\end{array}$ & $\begin{array}{c}0.264 \\
(0.168)\end{array}$ & $\begin{array}{c}0.280^{*} \\
(0.162)\end{array}$ \\
\hline Sec lending $i_{i, t}$ & $\begin{array}{l}6.647^{* * *} \\
(0.123)\end{array}$ & $\begin{array}{l}6.626^{* * *} \\
(0.124)\end{array}$ & $\begin{array}{l}6.636^{* * *} \\
(0.123)\end{array}$ & $\begin{array}{l}5.039^{* * *} \\
(0.304)\end{array}$ & $\begin{array}{l}5.037^{* * *} \\
(0.304)\end{array}$ & $\begin{array}{l}5.028^{* * *} \\
(0.302)\end{array}$ \\
\hline Short selling $_{i, t}$ & $\begin{array}{l}2.514^{* * *} \\
(0.443)\end{array}$ & $\begin{array}{l}2.603^{* * *} \\
(0.447)\end{array}$ & $\begin{array}{l}2.596^{* * *} \\
(0.445)\end{array}$ & $\begin{array}{c}-1.538^{* *} \\
(0.776)\end{array}$ & $\begin{array}{r}-1.492^{*} \\
(0.774)\end{array}$ & $\begin{array}{c}-1.633^{* *} \\
(0.783)\end{array}$ \\
\hline Options $_{i, t}$ & $\begin{array}{l}6.030^{* * * *} \\
(0.953)\end{array}$ & $\begin{array}{l}6.055^{* * *} \\
(0.955)\end{array}$ & $\begin{array}{l}6.030^{* * *} \\
(0.952)\end{array}$ & $\begin{array}{l}6.168^{* * * *} \\
(1.554)\end{array}$ & $\begin{array}{l}6.234^{* * *} \\
(1.571)\end{array}$ & $\begin{array}{l}5.670^{* * *} \\
(1.562)\end{array}$ \\
\hline Other practices $_{i, t}$ & $\begin{array}{c}-2.629^{* * *} \\
(0.333)\end{array}$ & $\begin{array}{c}-2.574^{* * *} \\
(0.333)\end{array}$ & $\begin{array}{c}-2.547^{* * *} \\
(0.333)\end{array}$ & $\begin{array}{l}2.800^{* * *} \\
(0.972)\end{array}$ & $\begin{array}{l}2.719^{* * *} \\
(0.966)\end{array}$ & $\begin{array}{l}2.162^{* *} \\
(0.962)\end{array}$ \\
\hline$N$ & $2,115,821$ & $2,115,821$ & $2,115,821$ & 449,609 & 449,609 & 449,609 \\
\hline Adjusted $R^{2}$ & 0.352 & 0.351 & 0.352 & 0.403 & 0.402 & 0.408 \\
\hline
\end{tabular}




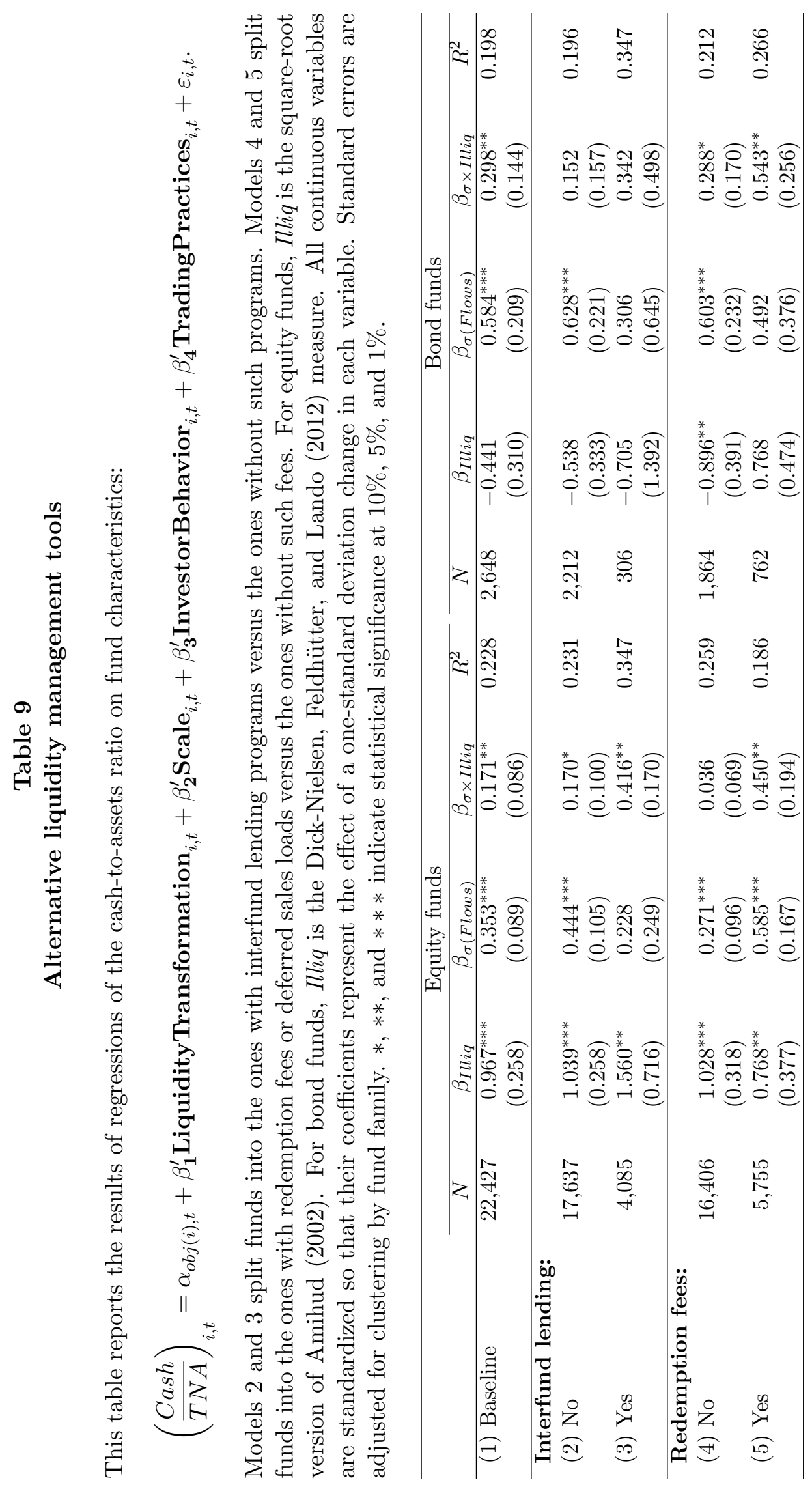




\section{Appendix}

\section{Table A1 Variable definitions}

$\frac{\text { Cash }}{T N A}$

$\frac{\Delta \operatorname{Cash}_{i, t-6 \rightarrow t}}{T N A_{i, t-6}}$

$\Delta\left(\frac{\text { Cash }}{T N A}\right)_{i, t-6 \rightarrow t}$

Flows

Illiq
Cash is cash $(74 \mathrm{~A})+$ repurchase agreements $(74 \mathrm{~B})+$ short-term debt securities other than repurchase agreements $(74 \mathrm{C})$ + other investments (74I). Other investments consist mostly of money market mutual funds but sometimes include holdings of long-term mutual funds. We subtract the latter based on security-level holdings data from CRSP Mutual Fund Database (for equity funds) and Morningstar (for bond funds). Cash is scaled by total net assets (74T). Winsorized at the 1st and 99th percentiles.

Change in cash between two semi-annual reporting periods divided by TNA as of the previous semi-annual reporting period. Winsorized at the 1st and 99th percentiles.

Change in the cash-to-assets ratio between two semi-annual reporting periods. Winsorized at the 1 st and 99th percentiles.

Net fund flows during each of the preceding six months (28) are scaled by TNA at the end of the previous semi-annual reporting period. Winsorized at the 5th and 95th percentiles. Appendix Table A2 reports the results of robustness checks using fund flows winsorized at the 1st and 99th percentiles.

Equity funds: We first calculate the square-root version of Amihud (2002) liquidity measure for each stock in a funds portfolio. We use daily data for the preceding six months. We then calculate the valueweighted average across all stocks held by a given mutual fund. Equity fund portfolio holdings are from the CRSP Mutual Fund Database. Winsorized at the 1st and 99th percentiles.

Bond funds: We first calculate Dick-Nielsen, Feldhütter, and Lando (2012) $\lambda$ measure for each bond in a fund's portfolio. We then calculate the value-weighted average across all corporate bonds held by a given mutual fund. Portfolio holdings are from Morningstar. Bond transaction data are from Enhanced TRACE. 


\section{Table A1-Continued}

Low Agg Liq

Family size

$\sigma($ Flows $)$

Institutional share

Turnover

Sec lending

Short selling

Options
For equity funds, we use the Pastor and Stambaugh (2003) measure of market liquidity. For bond funds, we use the aggregate version of Dick-Nielsen, Feldhütter, and Lando (2012). Periods of low aggregate liquidity are defined as those in the bottom tercile of the distribution of aggregate market liquidity within our sample.

Log of aggregate TNA across all CRSP mutual funds within the same family.

Standard deviation of monthly fund flows (28) over the preceeding six months. Fund flows are scaled by TNA as of the beginning of the semi-annual reporting period.

Fraction of institutional share classes, identified following Chen, Goldstein, and Jiang (2010). A share class is considered to be institutional if a) CRSPs institutional dummy is equal to $\mathrm{Y}$ and retail dummy is equal to $\mathrm{N}$, or $\mathrm{b}$ ) fund name includes the word institutional or its abbreviation, or c) class name includes one of the following suffixes: I, $\mathrm{X}, \mathrm{Y}$, or Z. Share classes with the word retirement in their name or suffixes $\mathrm{J}, \mathrm{K}$, and $\mathrm{R}$ are considered to be retail.

Portfolio turnover for the current semi-annual reporting period (71D). Portfolio turnover is the minimum of purchases and sales (including all maturities), divided by the monthly average value of the portfolio. Portfolio turnover is winsorized at the 1st and 99th percentiles.

Binary variable equal to one for funds that engage in loaning portfolio securities (70N).

Binary variable equal to one for funds that engage in short selling (70R). Average of 8 binary variables, each equal to one if a fund engages in writing or investing in 1) options on equities (70B), 2) options on debt securities (70C), 3) options on stock indices (70D), 4) interest rate futures $(70 \mathrm{E}), 5)$ stock index futures $(70 \mathrm{~F}), 6)$ options on futures $(70 \mathrm{G}), 7)$ options on stock index futures $(70 \mathrm{H})$, and 8 ) other commodity futures (70I). 


\section{Table A1-Continued}

Other practices

Redemption fees

Share of agg holdings

Share of outstanding

Overlap

Tenure

Experience

$A C T$
Average of 7 binary variables for engaging in the following investment practices: 1) investment in restricted securities (70J), 2) investment in shares of other investment companies $(70 \mathrm{~K}), 3)$ investments in securities of foreign issuers $(70 \mathrm{~L}), 4)$ currency exchange transactions $(70 \mathrm{M})$, 5 ) borrowing of money (70O),6) purchases/sales by certain exempted affiliated persons (70P), 7) margin purchases (70Q).

Binary variable equal to one for funds that impose a deferred or contingent deferred sales load (34) or a redemption fee other than a deferred or contingent sales load (37).

Weighted-average of the funds holdings of each security relative to aggregate holdings by all mutual funds: $\sum_{s} \frac{V_{f, s}}{\sum_{s} V_{f, s}} \times \frac{V_{f, s}}{\sum_{f} V_{f, s}}$, where $f$ indexes funds and $s$ indexes securities. For equities (bonds), aggregate fund holdings are calculated using CSRP (Morningstar).

Weighted-average of the funds holdings of each portfolio security relative to the security's outstanding amount: $\sum_{s} \frac{V_{f, s}}{\sum_{s} V_{f, s}} \times \frac{V_{f, s}}{\text { Outstanding }_{s}}$, where $f$ indexes funds and $s$ indexes securities. For stocks, the outstanding is the market capitalization, calculated using the price and number of shares reported in CRSP. For bonds, outstanding is the face value at issuance.

For each security $s$ held by fund $f$, we calculate aggregate holdings of security $s$ by all other funds that belong to the same family and divide this by the aggregate TNA of family funds, excluding fund $f$. We then take the value-weighted average across all securities held by fund $f$.

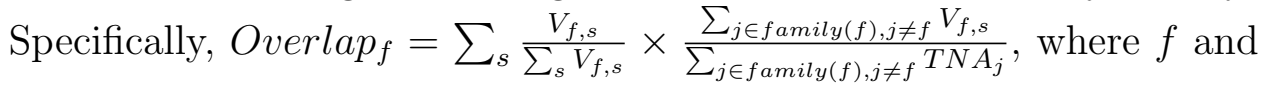
$j$ index funds and $s$ indexes securities.

Number of years managing the fund. For team managed funds, Tenure is the average across individual managers. Manager identities and characteristics are from Morningstar and cover the period through September 2013.

Number of years managing any mutual funds.

Average ACT score of the students admitted to the university from which the fund manager received his or her undergraduate degree. ACT scores are for the 2001-2002 incoming class. Source: National Center for Education Statistics, IPEDS Data Center. 


\section{Table A2}

\section{Flow management through cash holdings: Alternative winsorization}

This table shows the robustness of the flow management results to winsorizing fund flows at the 1st and 99th percentiles In columns (1) and (3), the dependent variable is the change in cash over a six-month period, scaled by assets six months ago. In columns (2) and (4), the dependent variable is the change in the cash-to-assets ratio over a six-month period. The independent variables are monthly net fund flows, scaled by net assets six months ago. Standard errors are adjusted for clustering by time. $*, * *$, and $* * *$ indicate statistical significance at $10 \%, 5 \%$, and $1 \%$.

\begin{tabular}{|c|c|c|c|c|}
\hline & \multicolumn{2}{|c|}{ Equity funds } & \multicolumn{2}{|c|}{ Bond funds } \\
\hline & $\frac{\Delta C a s h}{T N A}$ & $\Delta\left(\frac{\text { Cash }}{T N A}\right)$ & $\frac{\Delta \operatorname{Cash}}{T N A}$ & $\Delta\left(\frac{\text { Cash }}{T N A}\right)$ \\
\hline & (1) & $(2)$ & $(3)$ & $(4)$ \\
\hline \multirow[t]{2}{*}{$\overline{\text { Flows }_{i, t}}$} & $0.178^{* * *}$ & $0.060^{* * *}$ & $0.243^{* * *}$ & $0.091^{* * *}$ \\
\hline & $(0.017)$ & $(0.011)$ & $(0.046)$ & $(0.028)$ \\
\hline \multirow[t]{2}{*}{ Flows $_{i, t-1}$} & $0.135^{* * *}$ & 0.017 & 0.016 & -0.048 \\
\hline & $(0.023)$ & $(0.015)$ & $(0.042)$ & $(0.031)$ \\
\hline \multirow[t]{2}{*}{ Flows $_{i, t-2}$} & $0.113^{* * *}$ & 0.018 & $0.186^{* *}$ & 0.079 \\
\hline & $(0.024)$ & $(0.017)$ & $(0.071)$ & $(0.053)$ \\
\hline \multirow[t]{2}{*}{ Flows $_{i, t-3}$} & $0.097^{* * *}$ & -0.010 & 0.038 & -0.065 \\
\hline & $(0.020)$ & $(0.010)$ & $(0.069)$ & $(0.062)$ \\
\hline \multirow[t]{2}{*}{ Flows $_{i, t-4}$} & $0.061^{* * *}$ & -0.012 & 0.040 & -0.038 \\
\hline & $(0.021)$ & $(0.010)$ & $(0.053)$ & $(0.056)$ \\
\hline \multirow[t]{2}{*}{ Flows $_{i, t-5}$} & 0.003 & $-0.065^{* * *}$ & $0.145^{* *}$ & 0.002 \\
\hline & $(0.024)$ & $(0.015)$ & $(0.064)$ & $(0.033)$ \\
\hline$N$ & 19,212 & 19,212 & 2,515 & 2,515 \\
\hline Adjusted $R^{2}$ & 0.160 & 0.024 & 0.129 & 0.015 \\
\hline
\end{tabular}


Table A3

Cash-to-assets ratio and alternative measures of bond illiquidity

This table reports the results of the regressions of the cash-to-assets ratio on alternative measures of bond illiquidity:

$$
\begin{aligned}
\left(\frac{C a s h}{T N A}\right)_{i, t} & =\alpha_{o b j(i), t}+\beta_{\mathbf{1}}^{\prime} \text { LiquidityTransformation }_{i, t}+\beta_{\mathbf{2}}^{\prime} \text { Scale }_{i, t} \\
& +\beta_{\mathbf{3}}^{\prime} \text { InvestorBehavior }_{i, t}+\beta_{\mathbf{4}}^{\prime} \text { TradingPractices }_{i, t}+\varepsilon_{i, t} .
\end{aligned}
$$

$\lambda$ is the Dick-Nielsen, Feldhütter, and Lando (2012) measure of bond illiquidity. Amihud (2002) is calculated following Dick-Nielsen, Feldhütter, and Lando (2012). IRC is the Imputed Roundtrip Cost (Feldhütter 2012). $\quad \gamma$ is the Roll (1984) measure of illiquidity, calculated following Bao, Pan, and Wang (2011). All specifications include objective-time fixed effects. The sample period is January 2004-June 2012. All continuous variables are standardized so that their coefficients represent the effect of a one-standard deviation change in each variable. Standard errors are adjusted for clustering by fund family. $*, * *$, and $* * *$ indicate statistical significance at $10 \%, 5 \%$,

\begin{tabular}{|c|c|c|c|c|}
\hline & $\begin{array}{c}\lambda \\
(1)\end{array}$ & $\begin{array}{c}\gamma \\
(2)\end{array}$ & $\frac{\sqrt{A m i h u d}}{(3)}$ & $\begin{array}{c}I R C \\
(4)\end{array}$ \\
\hline \multirow[t]{2}{*}{$\sigma(\text { Flows })_{i, t}$} & $0.584^{* * *}$ & $0.770^{* * *}$ & $0.595^{* * *}$ & $0.564^{* * *}$ \\
\hline & $(0.209)$ & $(0.236)$ & $(0.212)$ & $(0.206)$ \\
\hline \multirow[t]{2}{*}{ Illiq $_{i, t}$} & -0.441 & $0.825^{* *}$ & -0.545 & -0.325 \\
\hline & $(0.310)$ & $(0.320)$ & $(0.364)$ & $(0.355)$ \\
\hline \multirow{2}{*}{ Illiq $\times \sigma(\text { Flows })_{i, t}$} & $0.298^{* *}$ & 0.202 & 0.204 & $0.338^{* *}$ \\
\hline & $(0.144)$ & $(0.295)$ & (0.131) & $(0.149)$ \\
\hline \multirow[t]{2}{*}{$S i z e_{i, t}$} & 0.207 & $0.547^{*}$ & 0.186 & 0.206 \\
\hline & $(0.348)$ & $(0.329)$ & $(0.345)$ & $(0.348)$ \\
\hline \multirow[t]{2}{*}{ Family size $_{i, t}$} & $-0.827^{* *}$ & $-0.896^{* *}$ & $-0.840^{* *}$ & $-0.823^{* *}$ \\
\hline & $(0.344)$ & $(0.372)$ & $(0.342)$ & $(0.345)$ \\
\hline \multirow[t]{2}{*}{ Institutional share $_{i, t}$} & $1.044^{* * *}$ & $0.865^{* *}$ & $1.041^{* * *}$ & $1.037^{* * *}$ \\
\hline & $(0.292)$ & $(0.334)$ & $(0.292)$ & $(0.294)$ \\
\hline \multirow{2}{*}{ Turnover $_{i, t}$} & 0.358 & 0.566 & 0.310 & 0.371 \\
\hline & $(0.432)$ & $(0.359)$ & $(0.429)$ & $(0.433)$ \\
\hline \multirow[t]{2}{*}{ Sec lending ${ }_{i, t}$} & $5.285^{* * *}$ & $5.113^{* * *}$ & $5.275^{* * *}$ & $5.267^{* * *}$ \\
\hline & $(0.756)$ & $(0.875)$ & $(0.760)$ & $(0.762)$ \\
\hline \multirow[t]{2}{*}{ Short selling $_{i, t}$} & -1.478 & $-2.409^{* *}$ & -1.496 & -1.476 \\
\hline & $(1.063)$ & (1.201) & $(1.062)$ & (1.067) \\
\hline \multirow[t]{2}{*}{ Options $_{i, t}$} & $7.250^{* *}$ & 6.231 & $7.200^{* *}$ & $7.323^{* *}$ \\
\hline & (3.238) & (3.990) & (3.208) & (3.207) \\
\hline \multirow{2}{*}{ Other practices $_{i, t}$} & 2.332 & 2.853 & 2.249 & 2.294 \\
\hline & $(1.664)$ & $(1.752)$ & $(1.655)$ & $(1.664)$ \\
\hline$N$ & 2,648 & 1,713 & 2,648 & 2,648 \\
\hline Adjusted $R^{2}$ & 0.198 & 0.228 & 0.197 & 0.198 \\
\hline
\end{tabular}
and $1 \%$. 


\section{Table A4 \\ Instrumenting for asset illiquidity and flow volatility}

This table reports the results of 2SLS regressions of the cash-to-assets ratio on asset illiquidity and flow volatility, instrumented with Lipper objective dummies interacted with fund age. OLS specifications include objective-date fixed effects. 2SLS specifications include date fixed effects. All continuous variables are standardized so that their coefficients represent the effect of a one-standard deviation change in each variable. Standard errors are adjusted for clustering by Lipper objective. $*, * *$, and $* * *$ indicate statistical significance at $10 \%, 5 \%$, and $1 \%$.

\begin{tabular}{|c|c|c|c|c|}
\hline & \multicolumn{2}{|c|}{ Equity funds } & \multicolumn{2}{|c|}{ Bond funds } \\
\hline & OLS & 2 SLS & OLS & $2 \mathrm{SLS}$ \\
\hline & $(1)$ & $(2)$ & $(3)$ & $(4)$ \\
\hline \multirow[t]{2}{*}{ Illiq $_{i, t}$} & $0.967^{* * *}$ & $1.700^{* * *}$ & -0.441 & -0.368 \\
\hline & $(0.258)$ & $(0.348)$ & $(0.310)$ & $(2.102)$ \\
\hline \multirow[t]{2}{*}{$\sigma(\text { Flows })_{i, t}$} & $0.353^{* * *}$ & $1.231^{* *}$ & $0.584^{* * *}$ & $2.614^{* * *}$ \\
\hline & $(0.089)$ & $(0.619)$ & $(0.209)$ & $(0.469)$ \\
\hline \multirow[t]{2}{*}{ Illiq $\times \sigma(\text { Flows })_{i, t}$} & $0.171^{* *}$ & $1.175^{* * *}$ & $0.298^{* *}$ & 3.267 \\
\hline & $(0.086)$ & $(0.437)$ & $(0.144)$ & $(3.834)$ \\
\hline \multirow[t]{2}{*}{$S i z e_{i, t}$} & 0.063 & 0.241 & 0.207 & $0.622^{* * *}$ \\
\hline & $(0.192)$ & $(0.200)$ & $(0.348)$ & $(0.158)$ \\
\hline \multirow[t]{2}{*}{ Family size $_{i, t}$} & $-1.298^{* * *}$ & $-1.148^{* * *}$ & $-0.827^{* *}$ & $-0.725^{* * *}$ \\
\hline & $(0.314)$ & $(0.123)$ & $(0.344)$ & $(0.216)$ \\
\hline \multirow[t]{2}{*}{ Institutional share $_{i, t}$} & 0.391 & 0.405 & $1.044^{* * *}$ & $0.764^{* * *}$ \\
\hline & $(0.247)$ & $(0.324)$ & $(0.292)$ & $(0.161)$ \\
\hline \multirow[t]{2}{*}{ Turnover $_{i, t}$} & -0.027 & -0.002 & 0.358 & 0.070 \\
\hline & $(0.146)$ & $(0.105)$ & $(0.432)$ & $(0.282)$ \\
\hline \multirow[t]{2}{*}{ Sec lending $g_{i, t}$} & $6.641^{* * *}$ & $6.726^{* * *}$ & $5.285^{* * *}$ & $5.347^{* * *}$ \\
\hline & $(0.619)$ & $(0.966)$ & $(0.756)$ & $(0.118)$ \\
\hline \multirow[t]{2}{*}{ Short selling ${ }_{i, t}$} & $3.194^{* * *}$ & $2.532^{* *}$ & -1.478 & $-1.985^{* *}$ \\
\hline & $(1.153)$ & $(1.061)$ & $(1.063)$ & $(0.965)$ \\
\hline \multirow[t]{2}{*}{ Options $_{i, t}$} & $5.388^{*}$ & $4.484^{* * *}$ & $7.250^{* *}$ & $6.748^{* * *}$ \\
\hline & $(2.799)$ & $(1.020)$ & $(3.238)$ & $(1.575)$ \\
\hline \multirow[t]{2}{*}{ Other practices $s_{i, t}$} & $-3.241^{* *}$ & $-3.452^{* * *}$ & 2.332 & $3.017^{* * *}$ \\
\hline & $(1.518)$ & $(0.836)$ & $(1.664)$ & $(1.088)$ \\
\hline$N$ & 22,427 & 22,427 & 2,648 & 2,648 \\
\hline Adjusted $R^{2}$ & 0.228 & 0.186 & 0.198 & \\
\hline
\end{tabular}




\section{Appendix: Model}

\section{A. Setup}

Throughout the paper, we use liquidity transformation to mean that the price-quantity schedule faced by a fund investor in buying or selling fund shares is different than it would be if the investor directly traded in the underlying assets. To help fix ideas, we begin by presenting a simple static model linking liquidity transformation to cash holdings. ${ }^{1}$ Consider a single mutual fund that has $M$ investors, each of whom has invested a dollar. Each investor is associated with outflows $x_{m}$ next period. For simplicity, we assume that these outflows are normally distributed, with mean zero and variance $\sigma^{2}$. Further, assume that the correlation of outflows across investors is $\rho$. This correlation captures, in reduced form, both that liquidity shocks may be correlated across investors and that flows may be correlated because they respond to past performance (i.e., there is a performance-flow relationship).

The fund may accommodate redemptions in two ways. First, it may choose to hold cash reserves $R$. These reserves are liquid claims that can be sold costlessly to meet outflows. In practice, these claims are supplied by the traditional banking system or shadow banking system, but, for simplicity, we model them here as existing in elastic supply. Each dollar of cash reserves is associated with carrying cost $i$. One may think of $i$ as the cost of tracking error for the fund. If it does not have sufficient cash reserves, the fund meets outflows by liquidating some of its illiquid security holdings. When it does so, the fund incurs average cost $c$ per dollar of sales.

Given these assumptions, the total outflows suffered by the fund are

$$
x=\sum_{m} x_{m} \sim N\left(0, \sigma^{2} M(1+(M-1) \rho)\right) .
$$

The fund chooses its cash reserves $R$ to minimize the sum of carry costs and expected liquidation costs:

$$
i R+\int_{R}^{\infty} c(x-R) d F(x)
$$

where $F$ is the cumulative distribution function of $x$.

\footnotetext{
${ }^{1}$ To get similar intuitions in a dynamic model, one needs to assume either convex costs of liquidating the illiquid asset or time varying liquidation costs. Zeng (2015) shows that these intuitions remain in a full-fledged dynamic model using the latter approach.
} 


\section{B. Discussion of setup}

This setup, though stylized, captures key features of how mutual funds perform liquidity transformation. The model is akin to the problem a fund faces at the end of a trading day. At the end of a trading day, the fund's NAV is set, so the fundamental value of the illiquid securities is fixed. We are normalizing the NAV so that the value of each investor's shares is $\$ 1$ and then allowing them to redeem some fraction of those shares. The fund then meets those fixed value redemptions in the optimal manner.

The fund in the model is performing liquidity transformation in two ways. First, it allows the investors to sell an unlimited fraction of their shares at a \$1 NAV despite the fact that the fund itself faces costs if it sells the illiquid asset. Second, the fund aggregates buying and selling across investors, costlessly netting trades between them and only selling the illiquid asset if it faces large net outflows. Individual investors trading for themselves in a market would only achieve this if they traded simultaneously. Outside of the model, the presence of a cash buffer allows funds to perform this kind of netting across longer periods of time.

The model could be generalized in two ways. First, we could more carefully model net inflows. As structured, the model is set up to consider how the fund manages outflows, but the fund faces a similar problem when it has inflows. On one hand, the fund increases its tracking error if it holds the inflows as cash. But on the other hand, holding cash reduces the price impact the fund generates in buying the illiquid asset. Thus, the logic of the model suggests that cash is useful for managing both inflows and outflows.

A second generalization would be to endogenize the volatility of investor flows. Presumably, the fact that investors do not directly face the costs of liquidation that they generate for the fund means that they are more willing to trade fund shares than they would be if they bore their own liquidation costs. This means that gross flows in the model are higher than gross trade would be in a setting where investors traded the illiquid asset themselves.

C. Optimal cash reserves for a single fund

We now solve for the fund's optimal holdings of cash reserves $R$. Proposition 1 characterizes the optimal reserve holdings $R^{*}$. 
Proposition 1. Assuming $i \leq \frac{c}{2}$, optimal cash holdings $R^{*}$ satisfy the first order condition $F\left(R^{*}\right)=1-i / c$. Because $\boldsymbol{x}$ is normally distributed, we have $R^{*}=k \sqrt{\sigma^{2} M(1+(M-1) \rho)}$, where $k=\Phi^{-1}(1-i / c)$, and $\Phi$ is the standard normal cumulative distribution function.

Proof: All proofs are given at the end of the Appendix.

Intuitively, the fund trades off the carrying costs of cash reserves against the expected liquidation costs. The fund always pays the carrying cost $i$, while if it carries zero cash, it pays liquidation costs only half of the time - when it has outflows. Thus, we need $i \leq \frac{c}{2}$ for the fund to hold any cash.

The fund engages in liquidity transformation in two ways. First, it diversifies across investor liquidity shocks: inflows from one investor can be used to meet outflows from another without incurring any liquidation costs. This is analogous to the way diversification across depositors allows banks to hold illiquid assets, as in Diamond and Dybvig (1983). Second, when $<\frac{c}{2}$, the fund uses cash holdings to further reduce its expected liquidation costs. These costs depend on total outflows, which are determined by the number of investors, the volatility of their individual outflows, and the correlation between the individual outflows.

It follows from the fund's trade off that optimal cash reserves are increasing in the fund's expected liquidation costs. Intuitively, if the fund chooses to hold more cash, it is choosing to pay higher carrying costs. This is optimal only if the fund faces higher expected liquidation costs. Thus, if we take expected liquidation costs as a measure of the amount of liquidity transformation the fund is performing on behalf of its investors, the fund's optimal cash holdings are a measure of the amount of liquidity transformation it performs.

Proposition 2: Let $L^{*}=\int_{R^{*}}^{\infty} c\left(x-R^{*}\right) d F(x)$ be the fund's expected liquidation costs when it holds the optimal amount of cash reserves. When $i \leq \frac{c}{2}$, optimal cash holdings are proportional to the expected liquidation costs: $L^{*}=R^{*}(c \phi(k) / k-i)$.

Let $r^{*}=R^{*} / M$ be the fund's optimal cash-to-assets ratio. Proposition 3 derives some simple comparative statics. 
Proposition 3. Assuming $\leq \frac{c}{2}$, optimal cash holdings $R^{*}$ and optimal cash-to-assets ratio $r^{*}$ satisfy the following comparative statics:

$\partial r^{*} / \partial c>0$ : The optimal cash-to-assets ratio increases with asset illiquidity.

$\partial r^{*} / \partial \sigma>0$ : The optimal cash-to-assets ratio increases with the volatility of fund flows.

$\partial^{2} r^{*} / \partial \sigma \partial c>0$ : The relationship between cash-to-assets ratios and fund flow volatility

is stronger for funds with more illiquid assets.

$\partial R^{*} / \partial M>0$ and $\partial r^{*} / \partial M<0$ : Optimal cash holdings rise with fund size. As long as

$\rho<1$, optimal cash-to-assets ratio falls with fund size.

$\partial^{2} r^{*} / \partial M \partial \rho>0$ : The optimal cash-to-assets ratio falls more slowly with fund size when investor flows are more correlated.

The first three comparative statics relate cash holdings to liquidity transformation. Liquidity transformation is driven by the intersection of investor behavior and asset illiquidity. If the fund faces more volatile flows, it is providing greater liquidity services to its investors. Similarly, if the fund's assets are more illiquid, it is providing greater liquidity services to its investors. Consistent with our insight that cash holdings are a measure of liquidity transformation, the fund optimally chooses a higher cash-to-assets ratio when it faces more volatile flows and holds more illiquid assets. These two effects interact: the more illiquid the assets, the stronger the relationship between cash-to-assets ratios and flow volatility.

The fourth and fifth comparative statics involve economies of scale in liquidity management. As the size of the fund rises, the volatility of dollar outflows rises. Thus, the fund must hold more cash reserves. However, because there is diversification across investors, the cash-to-assets ratio falls with fund size: the amount of additional cash reserves the fund holds for each incremental dollar of assets falls as fund size increases. The comparative statics also show that this diversification benefit dissipates as the correlation between individual investor flows rises. As flows become more correlated, economies of scale in liquidity management diminish.

\section{Internalizing price impact}

We next consider the problem of many funds and ask whether, in the aggregate, they hold enough cash to avoid exerting price impact externalities on one another. Suppose there are $G$ 
funds, each of size $M$. For simplicity, assume that flows to all funds are perfectly correlated. This simplifies the algebra but does not change the intuition. Further, suppose that the per-dollar of sales liquidation cost $c$ faced by an individual fund is a function of the total asset sales by all funds: $c=c\left(\sum_{j} x_{j}-R_{j}\right)$.

Fund $j$ now seeks to minimize costs

$$
i R+\int_{R}^{\infty} c\left(x-R+\sum_{k \neq j}\left(x_{k}-R_{k}\right)\right)(x-R) d F(x)
$$

Eq. (2) is the same as Eq. (1), except now we have the costs of liquidation $c$ depending on the reserve choices and flows faced by all $G$ funds. Differentiating with respect to $R$ and imposing a symmetric equilibrium $\left(R_{k}=R_{j}\right)$, we have:

$$
i-\int_{R^{*}}^{\infty}\left[c\left(G\left(x-R^{*}\right)\right)+\left(x-R^{*}\right) c^{\prime}\left(G\left(x-R^{*}\right)\right)\right] d F(x)=0
$$

Next, consider the problem of a social planner seeking to minimize costs across all mutual funds. ${ }^{2}$ The planner seeks to minimize

$$
G\left[i R+\int_{R}^{\infty} c(G(x-R))(x-R) d F(x)\right] .
$$

Crucially, from the planner's perspective, it moves all funds' cash reserves at the same time. In contrast, in the private market equilibrium, each individual fund treats other funds' reserve policies as fixed when choosing its own reserves. Essentially, in the private market equilibrium, an individual fund does not internalize the positive effect its cash holdings have on the liquidation costs faced by other funds. This can be seen in the planner's first order condition:

$$
i-\int_{R^{* *}}^{\infty}\left[c\left(G\left(x-R^{* *}\right)\right)+G\left(x-R^{* * *}\right) c^{\prime}\left(G\left(x-R^{* *}\right)\right) d F(x)\right]=0 .
$$

Eq. (5) is the same as the private market first order condition in Eq. (3), with one exception. In the last term, the effect of the choice of reserves on marginal costs of liquidation is multiplied by $G$. Essentially, the planner internalizes the fact that high reserves benefit all funds

\footnotetext{
${ }^{2}$ Note that for there to be a social loss in general equilibrium, the liquidation costs to the funds must not simply be a transfer to an outside liquidity provider. This would be the case if, as in Stein (2012), those outside liquidity providers had to forgo other positive-NPV projects in order to buy the assets being sold by mutual funds.
} 
through lower liquidation costs. Proposition 4 says that this leads the social planner to a higher level of reserves than the private market outcome.

Proposition 4: A planner coordinating among funds would choose a level of cash holdings $\boldsymbol{R}^{\text {*** }}$ higher than the level of cash holdings chosen in the private market equilibrium $R^{*}$.

A corollary that follows from this logic is that a monopolist in a particular security internalizes its price impact, particularly if that security is illiquid. The externality that makes private market cash holdings $R^{*}$ lower than the socially optimal level of cash holdings $R^{* *}$ arises because funds take into account how cash holdings mitigate their own price impact but not how that price impact affects other funds. Of course, if one fund owns the whole market, there is no externality. Generalizing this intuition, the higher is the fraction of the underlying assets owned by a given fund, the more will the fund internalize its price impact.

Corollary: Funds that own a larger fraction of their portfolio assets more fully internalize their price impact and therefore hold more cash reserves. 


\section{Proof of Proposition 1}

Differentiating the fund's objective function with respect to $R$ yields the first-order condition

$$
-i+c \int_{R}^{\infty} d F(x)=-i+c(1-F(R))=0 .
$$

Rearranging yields $F\left(R^{*}\right)=1-i / c$. Because $x$ is normally distributed with standard deviation $\sqrt{\sigma^{2} M(1+(M-1) \rho)}$, we have:

$$
\frac{x}{\sqrt{\sigma^{2} M(1+(M-1) \rho)}} \sim N(0,1),
$$

which is standard normal.

Proof of Proposition 2

Expected liquidation costs are given by

$$
\begin{aligned}
L^{*} & =\int_{R^{*}}^{\infty} c\left(x-R^{*}\right) d F(x) \\
& =c \int_{R^{*}}^{\infty} x d F(x)-R^{*}\left(1-F\left(R^{*}\right)\right) \\
& =c(\phi(k)) \sigma \sqrt{M(1+(M-1) \rho)}-R^{*} i \\
& =R^{*}(c \phi(k) / k-i) .
\end{aligned}
$$

\section{Proof of Proposition 3}

We have:

$$
r^{*}=k \sqrt{\sigma^{2}(1+(M-1) \rho) / M}
$$

where $k=\Phi^{-1}(1-i / c)$. Differentiation yields 


$$
\begin{aligned}
& \frac{\partial r^{*}}{\partial c}=\frac{\partial k}{\partial c} \sqrt{\sigma^{2}(1+(M-1) \rho) / M}>0 \\
& \frac{\partial r^{*}}{\partial \sigma}=k \sqrt{(1+(M-1) \rho) / M}>0 \\
& \frac{\partial^{2} r^{*}}{\partial \sigma \partial c}=\frac{\partial k}{\partial c} \sqrt{(1+(M-1) \rho) / M}>0 \\
& \frac{\partial r^{*}}{\partial M}=\frac{k}{2 M}\left(M \sigma^{2}+M(M-1) \sigma^{2} \rho\right)^{-1 / 2} \sigma^{2}(\rho-1)<0 \\
& \frac{\partial^{2} r^{*}}{\partial M^{2}}=\frac{k}{2 M}\left(M \sigma^{2}+M(M-1) \sigma^{2} \rho\right)^{-1 / 2} \sigma^{2}>0 .
\end{aligned}
$$

\section{Proof of Proposition 4}

The private market equilibrium is characterized by the first-order condition

$$
i-\int_{R^{*}}^{\infty}\left[c\left(G\left(x-R^{*}\right)\right)+\left(x-R^{*}\right) c^{\prime}\left(G\left(x-R^{*}\right)\right)\right]=0 .
$$

The social planner's solution is characterized by the first-order condition

$$
i-\int_{R^{* *}}^{\infty}\left[c\left(G\left(x-R^{* * *}\right)\right)+G\left(x-R^{* *}\right) c^{\prime}\left(G\left(x-R^{* *}\right)\right)\right]=0 .
$$

Evaluating the social planner's first-order condition at the private market equilibrium $R^{*}$ and substituting in the private market first-order condition, we have:

$$
\begin{aligned}
& i-\int_{R^{*}}^{\infty}\left[c\left(G\left(x-R^{*}\right)\right)+G\left(x-R^{*}\right) c^{\prime}\left(G\left(x-R^{*}\right)\right)\right] d F(x) \\
& =-\int_{R^{*}}^{\infty}\left[(G-1)\left(x-R^{*}\right) c^{\prime}\left(G\left(x-R^{*}\right)\right)\right] d F(x)<0 .
\end{aligned}
$$

Thus, the planner's first-order condition does not hold at the private market equilibrium $R^{*}$. Note that the planner's first-order condition is increasing in $R$, so we must have $R^{* *}>R^{*}$. 